\title{
Interpreting banks' sustainability initiatives as reputational risk management and mechanisms for coping, re- embedding and rebuilding societal trust
}

\begin{tabular}{|r|l|}
\hline Journal: & Qualitative Research in Financial Markets \\
\hline Manuscript ID & QRFM-02-2021-0024.R1 \\
\hline Manuscript Type: & Research Paper \\
\hline Keywords: & $\begin{array}{l}\text { Societal trust, sustainability initiatives, sustainable and green banking, } \\
\text { Equator Principles }\end{array}$ \\
\hline
\end{tabular}

\section{SCHOLARONE \\ Manuscripts}




\section{First: Introduction}

Societal trust in banks has collapsed as a result of excessive risk taking, poor structures for executive remuneration, inadequate risk management, unethical behaviour and poor social responsibility during the global financial crisis (Conyon et al., 2011; Kay Review, 2012; Ruiz et al., 2014; Solomon 2020; Walker Review, 2009). One only has to consider the bailout of banks considered 'too big to fail' (Conyon et al., 2011) to appreciate why society's faith and trust in banks has been rocked (Solomon, 2020). Berglof (2011) concluded that the financial crisis would refocus banks' attention on risk and risk management. Indeed, the destruction of banks' reputations following the global financial crisis has been well-documented in the academic literature (Dell'Atti et al., 2017; Englert et al., 2018; Forcadell and Aracil, 2017).

In addition to the collapse in trust and reputation arising from the financial crisis, banks are also witnessing the alienating effects of dis-embedding ${ }^{1}$ mechanisms, such as increased online banking, the closure of physical banks in towns and cities, the rise of call centres at the other side of the world from clients/customers, all of which represent abstract systems ${ }^{2}$ that create time-space distanciation. Such systems rely on societal trust at a time when trust in banks and in financial institutions generally is at an all-time low. The process of replacing face to face financial systems with 'faceless' commitments (Giddens, 1990; 1991) makes it harder for society to trust banks and other institutions. This need for trust in today's financial banking systems, combined with the collapse of societal trust arising from the financial crisis, has created an urgent need for banks to rebuild trust among their stakeholders and reinstate

\footnotetext{
1 Dis-embedding is defined as the 'lifting out' of social relationships from local contexts and their recombination across indefinite time/space distances (Giddens, 1991).

2 In Giddensian sociological language, abstract systems refer to symbolic tokens and expert systems, where symbolic tokens are defined as media of exchange that have standard value and are thus interchangeable across an indefinite variety of contexts (such as money or funds), and expert systems are defined as systems of expert knowledge, of any type, depending on rules of procedure transferable from individual to individual (Giddens, 1991). Expert systems can be interpreted as banking and financial systems.
} 
their reputations. The Kay Review raised this and provided a way forward for banks and other financial institutions (Kay Review, 2012).

As well as addressing reputational damage from the global financial crisis, banks face increasing challenges associated with climate change and related risks, and green/sustainable banking strategies can assist banks in restoring reputation (Dell'Atti et al., 2017; Englert et al., 2018; Forcadell and Aracil, 2017; Gallego-Alvarez and Pucheta-Martinez, 2019; Pérez and del Bosque, 2015). A sustainable approach to business represents an effective means of enhancing reputation as sustainability initiatives can assist in rebuilding stakeholder confidence (Fombrun, 2005; Forcadell et al., 2020). From a sociological perspective, sustainability initiatives, we suggest, represent re-embedding ${ }^{3}$ mechanisms, that can enhance societal trust in banking systems. Further, enhanced reputation can lead to higher levels of trust as it signals greater credibility (Nienaber et al., 2014).

Developing and implementing sustainability initiatives and practices is one way that organisations can enhance their reputation (Miras-Rodriguez et al., 2015; Delgado-Marquez and Padauga, 2017; Fanasch, 2019; Kim et al., 2009; Lai et al., 2016; Orlitzsky et al., 2003; Park, 2018; Torelli et al., 2019).

This paper seeks to explore the application of sustainability in relation to banks' implementation of sustainability initiatives such as the Equator Principles, through extensive interviews with representatives from leading banks based in the UK. Further, we interpret the interview data through a theoretical framework around risk and risk management, deriving from sociology, especially the works of Giddens and Beck. We interpret the interview findings through a lens of sociological theory that reveals sustainability initiatives to be imbued with reputational risk management but also indicates that some sustainability

\footnotetext{
${ }^{3}$ The online Oxford Reference defines re-embedding as, "New forms of social relations, communities, and politics (see globalization) arising alongside a decline in traditional forms of social cohesion", https://www.oxfordreference.com/view/10.1093/oi/authority.20110803100410665
} 
initiatives were interpreted as coping mechanisms and mechanisms of re-embedding. Our analysis allows conclusions to be drawn on the effectiveness of initiatives introduced by the banks interviewed in enhancing societal welfare, protecting the environment, and working towards reducing climate change.

\section{Second: A review of sustainable banking, green banking and the Equator Principles}

As the world continues to witness unprecedented anthropogenic climate change and its impact on societies and biodiversity, attention is turning increasingly to the finance industry to encourage banks, institutional investors, businesses and the accounting firms to incorporate social environmental and sustainability concerns into their decision-making and strategies (Solomon, 2020; Scholtens, 2017; Atkins and Macpherson, 2019; Atkins and Atkins, 2019). Such high consequence risks are an intrinsic part of $21^{\text {st }}$ century societies, being “...risks deriving from the globalised character of the social systems of modernity", as, "...nature, ...has in a certain sense come to an 'end' - as a result of domination by human beings - the risks of ecological catastrophe form an inevitable part of our horizon of day-to-day life" (Giddens, 1991, p.4). Indeed, Giddens considers climate change to constitute a fundamental threat to the future of global industrial civilisation (Giddens, 2009).

Globally, organizations are seeking to balance environmental, social and economic performance through sustainable development (SD hereafter) practices (Boiral, 2006; Jabbour and Jabbour, 2009; Hubbard, 2009; Baumgartner and Ebner, 2010; Shen et al., 2012; Ortizde-Mandojana and Bansal, 2015; Raut et al., 2017; Ozbekler and Ozturkoglu, 2020). Indeed, the social and environmental impacts of banks and other financial institutions have been recognised for some time as significant factors contributing to effective corporate governance (Coulson, 2009). The indirect impacts of banking on the environment are substantial and 
therefore they have an important role to play in SD through implementing sustainability initiatives (Beck et al., 2010; Yip and Bocken, 2018; Forcadell et al., 2020).

In the area of banking and sustainability, there is a growing literature focusing on 'green banking', which includes research into environmental protection through banks' investment in goods and services (Lindenberg and Volz, 2016). Indeed, there are two areas of sustainable and green banking that have attracted research interest: firstly, banks' internal initiatives, such as reducing paper usage and waste, and secondly, external initiatives, involving how the banks choose to invest funds (Sarma and Roy 2019). Some of the prior literature has focused on the advantages and disadvantages of green banking (Kapoor, Jaitly, and Gupta 2016). Various studies have considered the attitudes of bankers (Masukujjama et al. 2016; Mehedi, Kuddus, and Maniruzzaman 2017). Other research has concentrated on banking clients (Bryson et al. 2016; Prakash Pillai and Praveen Raj 2019; Deepa and Karpagam 2018), while some have studied penetration among the bankers.

'Green Banking' has evolved that seeks to limit banks' climate change impacts, at the same time investing in environmental goods and services (Lindenberg and Volz, 2016). One only has to consider recent media coverage of pressures from activist environmental Nonegovernmental Organisations (NGOs hereafter) on banks and financial institutions to appreciate the growing societal voice, for example the recent forced closures of Barclays branches in response to Greenpeace action. ${ }^{4}$ In recent years, banks have been responding to calls for greater accountability in relation to sustainability, and especially environmental issues, in primarily two ways: internally, by introducing social and environmental initiatives such as recycling and waste reduction, and; externally, by developing and applying social and environmental criteria to their lending decisions (Sarma and Roy, 2019). This second

\footnotetext{
${ }^{4}$ See article on the BBC website entitled, "Climate Change: Greenpeace Stops Barclays from Opening Branches" at https://www.bbc.co.uk/news/business-51702865 Accessed on $2^{\text {nd }}$ March 2020
} 
category of initiatives represents in part a response to the establishment of global principles and guidelines such as the Equator Principles. The role of the banking sector in allocating funds affords banks the potential to influence companies and organisations generally to become more sustainable and to pay greater attention to social and environmental considerations (Jeucken, 2010).

The introduction of the Sustainable Development Goals (SDGs hereafter) by the United Nations (UN hereafter) is driving governments and organisations across all sectors to adopt proactive measures and initiatives to address the challenges posed by the 17 SDGs. Such pressures were originally designed on a voluntary basis to manage these considerations in more effective and transparent sustainability principles (Macve and Chen, 2010). They aim to explore how business organisations could use accounting tools and practices to apply sustainability principles to manage the main imperatives of SD. These imperatives involve a set of different dimensions to ensure fair and equal allocation of resources and opportunities between current and future generations/ stakeholders (Gray and Milne, 2002). The effective management of these dimensions requires sensible considerations of some business imperatives e.g. fairness, accountability and ethical responsibilities (Grubnic, et al., 2015). Moreover, these imperatives involve incorporating climate change; ecological biodiversity, carbon emissions; human rights issues; global water shortage problems, and income and gender equality into core business activities. The determination of the needs of future stakeholders (generations) involve some measurement challenges and difficulties to predict these future needs and expectations (McElroy and Engelen, 2012). These developments are occurring across all sectors including the financial industry, with initiatives such as the Equator Principles being implemented by banks and other financial institutions. Despite these developments, the banking sector has been relatively under-researched in the area of SD, in 
comparison to other sectors (Raut et al., 2017). We seek to address this relatively underresearched research gap.

The Equator Principles are one of the most significant external sustainability initiatives that banks around the world can engage. They represent a risk management framework, adopted by financial institutions, for determining, assessing and managing environmental and social risk in project finance (Equator Principles, 2014). They are perceived as a risk management approach (Abb et al., 2017). The Equator Principles are primarily intended to provide a minimum standard for due diligence to support responsible risk decision-making. The Principles apply globally, to all industry sectors and to four financial products: project finance, advisory services, project-related corporate loans and bridge loans. The Equator Principles Association is the unincorporated association representing the member Equator Principles Financial Institutions (EPFIs hereafter) and Associates whose objective is the management, administration and development of the Equator Principles (Equator Principles, 2014). This umbrella Association was formed on 1 July 2010 with the aim of ensuring longterm viability and ease of management of the member EPFIs and Associates (ibid). An EPFI is a financial institution which has adopted the Equator Principles in accordance with the procedures in these rules, is active in project finance and whose name appears as an EPFI on the list of EPFIs and Equator Principles working groups. Each EPFI shall introduce and implement its own internal social and environmental risk management policies, procedures and standards in order to comply with the Equator Principles. All EPFIs have to apply all the principles to all new projects over $\$ 10 \mathrm{~m}$ from the date of adoption. The objectives of the Equator Principles are to: Promote and encourage the adoption of the Principles by more financial institutions; Promote and encourage the implementation of the Principles by the EPFIs and Associates in a manner consistent with good international banking practice and all applicable law and that offers reasonable consistency of approach; Develop the Principles as 
the EPFIs and Associates consider appropriate, having regard to developments in international practice, the evolution of sustainability standards, and the practices and the views of stakeholders; Maintain contact and share expertise with international financial institutions and other bodies who have developed their own social and environmental standards (Equator Principles, 2014).

The adoption of the Equator Principles is open to any financial institution that meets the relevant adoption requirements and agrees to meet the on-going reporting requirements. Adoption by a financial institution is voluntary but once such adoption has been made, the adopting entity must take all appropriate steps to implement and comply with the Equator Principles (Equator Principles, 2014).

\section{Third: Theorising banking sustainability initiatives through sociological and financial}

\section{frameworks}

The Equator Principles have become the financial industry standard for environmental and social risk management in project finance in some countries (Scholtens and Dam, 2007). Financial institutions adopt the Equator Principles to ensure that the projects they finance are developed in a socially responsible manner and reflect sound environmental management practices. By doing so, negative impacts on project-affected ecosystems and communities should be avoided where possible, and if unavoidable, should be reduced, mitigated and/or compensated for appropriately. Adopters believe that the adoption of, and adherence to, the Principles offer significant benefits for themselves, and for their borrowers and local stakeholders through their borrowers' engagement with locally affected communities (Ibid). Adopters should be able to better assess, mitigate, document and monitor the credit and reputation risk associated with financing development projects. Additionally, the collaboration and learning on broader policy application, interpretation and methodologies between adopters, and with their stakeholders, helps knowledge transfer, 
learning and best practice development (Macve and Chen, 2010). The adopters' role as financiers affords them opportunities to promote responsible environmental stewardship and socially responsible development.

The relevant thresholds and criteria for their application is described in detail in the Scope section of the Equator Principles EPFIs commit to implementing the Principles in their internal environmental and social policies, procedures and standards for financing projects and will not provide project finance or project-related corporate loans to projects where the client will not, or is unable to, comply with the Principles. While they are not intended to be applied retroactively, EPFIs apply them to the expansion or upgrade of an existing project where changes in scale or scope create significant environmental and social risks and impacts, or significantly change the nature or degree of an existing impact.

Recent research shows that 94 EPFIs in 37 countries have officially adopted the Equator Principles, covering many international project finance debt in emerging markets (Equator Principles, 2014). The Principles have increased the attention and focus on social/community standards and responsibility, including robust standards for indigenous peoples, labour standards, and consultation with locally affected communities within the project finance market. They have also promoted convergence around common environmental and social standards. Multilateral development banks, including the European Bank for Reconstruction and Development, and some credit agencies through the Organisation for Economic Cooperation and Development (OECD) are increasingly drawing on social and environmental standards as the Principles.

Another series of external sustainability initiatives include the shared effort to promote responsible environmental and social management practices in the financial sector and banking industry from The United Nations Environmental Programme Finance Initiative (UNEP FI hereafter). These initiatives have provided a platform for engagement with a broad 
range of interested stakeholders, including non-governmental organisations (NGOs), clients and industry bodies (UNEP FI, 2018).

Sociologists have sought to understand and theorise shifts in societal attitude associated with the emergence and increasing awareness of global threats to people and the planet for several decades. Ulrich Beck and Anthony Giddens, German and British sociologists respectively, have been significant in contributing to this understanding. Beck's (1992) risk society thesis built upon the characteristics of modernity (Giddens, 1990; 1991), identifying risk as a primary factor shaping society, institutions, politics and individual life choices. Beck defined risk society as, "a systematic way of dealing with hazards and insecurities induced and introduced by modernisation itself (Beck 1992:21)". Further, Giddens defined risk society as, "...a society increasingly preoccupied with the future (and also with safety), which generates the notion of risk," (Giddens and Pierson 1998, p.209). Altering financial systems and institutions such as banking is essential if the world is to adapt to impending climate change risks and alter the path, as, “... there has to be a profound restructuring of financial markets themselves and of banking" (Giddens, 2011, p.150).

\section{Fourth: Ecological risks: dis-embedding, re-embedding, coping mechanisms and ontological security}

One focus of Giddens' and Beck's work has been the ecological dimension of the risk society, as they perceived that humans' impact on the natural environment was affecting society at a deep level through the catastrophic risks faced by environmental degradation. Beck (1997) suggested that the way in which institutions were organised was not appropriate for the effective management of risk in a risk society. In the face of severe ecological problems, companies fall into either, "... the role of villain and poisoner, or ... the role of the hero and helper and celebrate this publicly.... " (Beck, 1997, p.61). 
Giddens, in The Politics of Climate Change (Giddens, 2011) explored the unprecedented challenges faced by humans and capitalism arising from anthropogenic global warming and related effects. Beck (1997) described two constellations in the ecological conflict. One is characterised by confrontation, where polluter industries and affected groups confront each other. He explained that this constellation only begins to change when a second emerges where external interested parties get involved and the collaboration between polluters and victims which covers up the 'truth' starts to disintegrate. This happens as the industry recognises it is part of a risk society. Accountability for the emergence of high consequence risks and their impact is difficult to pinpoint due to chains of inter-related responsibility. It is almost impossible in our society, which is characterised by complicated webs of inter-linked accountability, to attribute blame or responsibility to anyone source. Scientific proof of linkage between cause and effect relating to risk analysis is being used as a means of dismissing risks. Beck also suggested that by insisting on scientific proof of causality, companies were able to escape accountability.

"By turning up the standard of scientific accuracy, the circle of recognised risks justifying action is minimized, and consequently, the scientific license is implicitly granted for the multiplication of risks. To put it bluntly: insisting on the purity of the scientific analysis leads to the pollution and contamination of air, foodstuffs, water, soil, plants, animals and people. What results then is a covert coalition between strict scientific practice and the threats to life encouraged or tolerated by it" (Beck, 1992, p.62).

The sustainability-related risks associated with business activity have many characteristics described by Beck (1992) and Giddens (1991). Firstly, the risks in contemporary society 
differ from risks in previous eras as they are invisible and difficult to detect. For example, radiation or pollutants in farmed produce are not detectible to the nose or eye, only their effects are felt. Another characteristic of risks in the situation of late modernity is that their consequences will be devastating for communities, the environment or biodiversity. They are, in Giddens' (1991) terms, 'high consequence' risks. The emergence of high consequence risks, especially social, environmental and sustainability risks, has been highlighted as a societal trend (Giddens, 1991; Beck, 1992). This proliferation of high consequence risks has posed problems for society and especially for companies, who have been held increasingly accountable for their creation. ${ }^{5}$ Beck (1997) focused specifically on ecologically-derived risks and their effects on society, institutions and politics. The awareness of high consequence risks which represent dangers from which no one can be completely free has now become part of individuals' 'umwelt', the cocoon of relevance and normalcy with which individuals surround themselves in order to place themselves in the world (Goffman, 1971). Giddens (1991) defined an individual's protective cocoon as the mantle of trust that makes possible the sustaining of a viable Umwelt. This trust incorporates an attempt by individuals to come to terms with high consequence risk, either by accepting them, actively trying to reduce them (by recycling, for example) or by giving up worrying about them. The threat of climate change and the potentially apocalyptic implications arising from human impacts on the planet, nature and the environment are threatening to people's ontological security, making them feel insecure in the face of high consequence risks.

Beck (1999) explains that risk in the era of the 'risk society' involves approaches aimed at foreseeing and controlling the future unintended consequences arising from human actions

\footnotetext{
${ }^{5}$ The emergence of high consequence risks represents the dark side of modernity, being created by the rapidity of social and technological change. The types of risk falling into this category arise from the 'human control of natural and social worlds' (Giddens, 1991, p.109). Specifically, Giddens (1990) sketched an array of high consequence risks including the growth of totalitarian power, the collapse of economic growth, nuclear conflict or large-scale warfare, and ecological decay or disaster. Clearly, sustainability risks arising from corporate activity represent a significant ingredient in the materialisation of these high consequence risks.
} 
and states that the risks from modernisation are irreversible threats to people, flora and fauna (Beck, 1992). The growth of the media has also contributed greatly to the increase in awareness of risks, especially in the sustainability area. Giddens (1991) discussed the way in which the development of electronic media has contributed to the construction of a reflexive modernity.

A further characteristic of the risk society thesis is that people are so overwhelmed by risk information that there is a tendency for them to stop caring (Beck, 1992). There is a general state of apathy among members of society arising from a feeling of helplessness. People switch off to risks because it is not 'normal' to worry constantly about high consequence risks such as nuclear war, as this would detract from coping with the practical aspects of everyday life. There is a numbing effect on society of constantly listing dangers, which creates apathy (Giddens, 1990). This also translates into feelings of 'engulfment' (Giddens, 1990, p.193) where people feel so overwhelmed by the potential risks and consequences arising from global warming and climate change that they cannot cope and react by trying not to contemplate these consequences: another response is to develop coping mechanisms, that can help to restore their ontological security. Another aspect of the risk society is that all 7 social classes are affected by risks. Whereas previously there was a division whereby higher classes could avoid risks, they cannot avoid the high consequence risks now pervading the economy.

We suggest that from a risk society theoretical perspective, banks' sustainability initiatives represent forms of coping mechanism, by which bank employees can feel they are addressing sustainability and related ecological risks through implementing initiatives. Such initiatives were interpreted as a means of re-embedding, rebuilding relationships between banks, their clients and other stakeholders. Perceiving sustainability initiatives in this way also leads us to 
consider the trust dimensions of the risk society theoretical framework and how this will be interpreted in relation to banks' sustainability initiatives.

\section{Fifth: Trust and Risk: Sustainability initiatives as a means of restoring societal trust}

One of the salient characteristics of the risk society have been identified as a loss of trust. However, the interpretation of the role of trust in a risk society differs from the work of Beck and Giddens. Whereas Beck considered that the monumental rise in societal risk in recent years has created a less trusting, confident society, characterised by societal anxiety, Giddens' view is somewhat different. Giddens (1990) considered that there is not necessarily a higher level of risk, but that society has become more reflexive. This increase in reflexivity has led to a decline in trust, which in turn has led society to be more anxious and more preoccupied with risks and their potential consequences. Again, reflexivity has been flagged up as a cornerstone of the risk society thesis, but there are various interpretations of the term and its implications (see, for example, Giddens, 1990, p.36).

From a Giddensian viewpoint, institutions face a crisis of trust, given the current trend in society to lose trust in institutions and organisations (Giddens, 1992). Further, sociologists have claimed that society is turning to counter-experts to replace the loss of confidence in traditional experts (Beck, 1992). Giddens (1990) explored the relationship between trust and risk. He examined the relationship between confidence and trust, suggesting that a distinction between the two has been made whereby trust should be understood specifically in relation to risk. He explains that,

"risk largely replaces what was previously thought of as Fortuna (fortune or fate) and becomes separated from cosmologies. Trust presupposes an awareness of circumstances of risk, whereas confidence does not. Trust and confidence both refer to expectations that can be frustrated or cast down (Giddens, 1990, pp30-31). 
He then goes on to set down his theory of risk and trust as follows. Trust is linked with contingency rather than with risk. Trust always carries the connotation of reliability in the face of contingent outcomes. Giddens stated that risk and trust intertwine and that trust generally serves to reduce or minimise the dangers to which particular types of activity are subject. In other words, building and establishing trust represents, in the Giddensian risk society framework, a form of risk management. Restoring trust and building confidence is a way of managing risk and therefore reducing societal anxiety, countering a loss of ontological security. There are some circumstances in which patterns of risk could be institutionalised, within surrounding frameworks of trust (stock market investments, for example).

Preserving corporate image, managing impressions and maintaining a 'good' external reputation among stakeholders is an integral part of Beck's risk society, as he explains,

"Those who find themselves in the public pillory as risk producers refute the charges as well as they can, with the aid of a 'counter-science' gradually becoming institutionalised in industry, and attempt to bring in other causes and thus other originators. The picture reproduces itself. Access to the media becomes crucial. The insecurity within industry intensifies: no one knows who will be struck next by the anathema of ecological morality. Good arguments, or at least arguments capable of convincing the public, become a condition of business success. Publicity people, the argumentation craftsmen, get their opportunity in the organisation (Beck, 1992, p.32).

Although banks, like other organisations, are aware of the need to implement sustainability initiatives and introduce SD strategies and policies, the risks attached to the concept of sustainability was less clear. Banks implement sustainability initiatives in a state of nichtwissen (not knowing), a concept discussed in Beck's risk society thesis. What risks are these initiatives being introduced to manage? Climate change? Social inequalities? Are these 
social and environmental risks manageable? How are they manifesting themselves? Why and how are these initiatives going to 'manage' these risks? If there is little or no understanding of the risks being addressed by such initiatives, then why are they being introduced at all? The interviews discussed in this paper provide some appreciation of the motivations underlying their introduction.

We consider that sustainability initiatives represent re-embedding and risk management mechanisms, especially the large-scale external initiatives such as the Equator Principles as they are a means of rebuilding societal trust in the banking sector, at the same time seeking to manage the risks arising from climate change, including reputational risk. Further, we suggest that some sustainability initiatives represent coping mechanisms, providing bank employees with an impression that they are controlling or mitigating the overwhelming risks associated with climate change and restoring their ontological security, giving them an illusion of control in the face of global catastrophic climate risk.

\section{Sixth: Research method}

For this study we conducted 25 semi-structured interviews with senior representatives of 16 small and medium-sized banks operating in the UK. The interviewees' details are presented in Table 1. The interview invitations were sent out to all the targeted interviewees via email and social media. Most of the targeted interviewees were accessed through the customer services department and call centres. Through the data analysis process, some direct quotes from the interview transcripts and collected documents have been used to refer to some issues that entail significant topics to present or argue. The level of significance was determined based on the interviewees' responses and perceptions toward the main research topics and questions. The interviewees' quotes were coded in random alphabetical characters in order to ensure the interviewees' anonymity and confidentiality as indicated in the interview consent 
forms that have been signed by all interviewees. In order to study sustainable finance, banks seemed the appropriate focus for the study as they represent one of the most significant groups of financial intermediaries in the economy to manage SD and support the transition plans for a green economy. We interviewed both mainstream banks and banks with social/environmental and/or charitable objectives.

Risk mitigation is one of the four functions of a bank, according to Jeucken (2004). Risk mitigation by banks can achieve a positive impact on society. Banks have an extensive and comparative advantage in the information held (as a result of the knowledge they have of economic sectors, regulations and market developments). Furthermore, banks transform the economic resources in terms of duration, value, spatial location, and risk (see Bihari, 2010; Jeucken, 2004 and (San-Jose, et al., 2011). So, they have an embedded influence on economic growth and the welfare of societies. Therefore, it can be argued that they have a social responsibility for their investment and financing decisions to support SD. Further, the UK banking sector includes some international banks involved in SD from an Islamic perspective (e.g. Al Rayan Bank and Qatar Islamic Bank- UK QIB). Confidence in the Islamic finance system emerges from what has been claimed to be the better understanding of sustainability supported by a complete and deep social ideology to operate more ethically and responsibly within society (Aklitar, 2007). Interestingly, the UK government established the world's first investment bank solely dedicated to greening the economy in 2011. The primary purpose of this initiative is to set the UK firmly on course towards a green and growing economy, and also delivering long-term sustainable growth. Therefore, the banking industry has drawn global attention in the last few years as one of the influential sectors in the economy in the field of SD (Bihari, 2010). These banks are suppliers of debt capital as well as being institutional investors in their own preferences, so the researchers want to explore the application of sustainability principles. Also, the banking sector could be seen as one of 
the main sectors that could be able to manage SD. The banking sector can accumulate detailed business experience of many economic sectors and markets. This accumulated experience is gained from their own lending, investment and operational activities. Furthermore, the United Nations established, in 1992, the UNFI EP Initiative (UNEP FI, $2011)^{6}$. This Initiative represents an international partnership between the United Nations Environment Programme and the global financial sector. The main purpose of this initiative is to develop and manage linkages between sustainability and financial performance. Accordingly, it seems particularly relevant to explore how sustainability practices could be applied in the UK banking sector.

Thematic analysis was used to analyse the interviewees' practices as more than mere factors responding to the world (Miles, et al., 2014). This approach enables researchers to explore different realities around social or human activities, and permits them to understand the behavioural contexts in which interviewees are involved (ibid). Therefore, the power of the qualitative research method focuses on exploring the meaning of words rather than quantification in the collection and analysis of data (Bryman and Bell, 2007). These deliberations have been carefully considered in developing the semi-structured interview questions in order to achieve the main research objectives. The average length of interviews was 50 minutes. All interviews were recorded and transcribed. The transcriptions were

\footnotetext{
${ }^{6}$ The three main sectors of finance, banking, insurance and investment, are represented and brought together in this global partnership. In addition, UNEP FI develops selective collaborations, UN-driven and finance sectordriven, with other partner organizations, in order to increase awareness and raise support for critical SD activities. UNEP FI contributes the perspectives of financial institutions to the various United Nations and global activities on sustainable finance. UNEP FI's activities are embedded throughout many disciplines specifically the work areas of Climate Change, Ecosystems Management, Energy Efficiency and Social Issues such as creating capacity building and the sharing of best practices; setting global standards and principles and engaging stakeholders, both public and private. For more information see http://www.unepfi.org/ (Accessed on 4th January 2017)
} 
analysed interpretively, drawing themes from the data and coding interviewees' utterances through reading and re-reading.

\section{Table 1}

\section{Interviewees' details and coding}

\section{Seventh: Empirical research findings}

This section presents the findings from the interview analysis according to three overriding themes, namely: (i) the interviewees' attitudes towards the Equator Principles and other external sustainability initiatives; (ii) sustainability initiatives as risk management and reembedding mechanisms, and; (iii) sustainability initiatives as coping mechanisms.

\subsection{Interviewee's attitudes towards the application of sustainability principles Most of} the interviewees were generally aware of the Equator Principles and one provided us with an in-depth description of how they were implemented in practice by their bank,

"The Equator Principles are a voluntary set of standards for determining, assessing and managing social and environmental risk in project financing. We signed the Equator Principles, which are applied to all our projects irrespective of the USD10 million capital costs threshold. We are actively involved in a strategic review launched by the Equator Principles Association in October 2010 to determine the future of the Equator Principles and to encourage greater consistency in the application of the Equator Principles in our markets. Under the Equator Principles, Environmental and Social risks are classified as: low (Category C), medium (Category B) or high (Category A). We report annually on the number of advisory and lending mandates executed by [our bank]" (F24).

Another interviewee highlighted their bank's commitment to ensuring that all lending is strictly against social and environmental criteria, 
"Well in terms of responsibility to our investment and lending decisions, all of our projects are screened by the environment and sustainability department. We will decide the appropriate steps in terms of both due diligence and structuring of the project, to ensure that the project meets our standards" (F4).

Another interviewee emphasised the importance of ensuring that companies fit lending criteria on social and environmental issues relating to the Equator Principles,

"Our major concern is to make sure that the companies that we are lending to actually fit the criteria that we set out to ensure that they are green and sustainable" (F12).

One interviewee mentioned the 'three pillars' applied to all investment or lending projects, "Sustainability, coming at it from my perspective, I would say it's one of the key elements of the strategy of the bank. We have three key pillars, which every project is required to meet, and these are the tests of transition. How does the project contribute to the transition to market economy process? ... So when you ask about the responsibility in investment and lending decisions, everything is screened for its environmental and social impact. All of the operations we do" (F5).

Both of the above quotes suggest from a Becksian and Giddensian theoretical perspective that following the Equator Principles were interpreted as a means of conveying and assuring the trustworthiness of the banks' compliance with the sustainability lending criteria. In this way, these 'pillars' and lending criteria were seen as mechanisms of re-embedding societal trust in the banking sector in the face of global warming and climate change.

Interestingly, although aware of the Equator Principles, and the social and environmental issues covered by them, one interviewee seemed a little uncertain of their name,

"The bank is a member of - what do you call it Equator Principles. So, any transaction or project that the bank finances need to comply with the Equator Principles. So that covers all social and environmental aspects" (F8).

This suggests that even though the Principles are being applied to rebuild trust, interpreting the utterance through a Giddensian, there is a lack of 'buy-in' to this substantial external 
initiative. Perhaps the Equator Principles are more about managing reputational risk than a genuine attempt to rebuild and nurture societal trust, which is in line with a business case, or instrumental ethics scenario (Solomon, 2020). There was further evidence of an instrumental ethics approach to implementing sustainability lending initiatives, such as the Equator Principles. One interviewee did however underline the importance of also making financially feasible lending decisions, although this priority seemed to be a 'given' after the fulfilment of socially acceptable criteria were met,

"We need to be convinced that there is a social return, otherwise we cannot lend, but we also need to be convinced that we are going to get our money back. Otherwise, also, we cannot lend" (F13).

A similar, instrumental ethics approach is enshrined in the following comment, from the senior financial officer from a mainstream bank,

"We have an obligation to produce a certain return for our shareholders, as does every other bank. So I think if you can be nice to the environment as well, then great, but if there are two competing options, one with a higher return than the other, then we would go with the higher return option" (F17).

It is interesting that this rather short-sighted and outdated view persists. Separating profit and return from sustainability was proven invalid through the growth and expansion globally of the responsible investment movement. Specifically, the significant shift in attitude among the institutional investment community from one where they perceived socially responsible investment to involve sacrificing financial returns for social returns, to one where they started to appreciate how financial and social returns can be positively related, an enlightened shareholder approach (Solomon, 2020). Sadly, members of the banking community continue to be blind to these linkages. Or do they? Indeed, the (obvious) need to focus on profits and 
profitability as well as on social and environmental concerns was, as would be anticipated, highlighted by interviewees, such as ${ }^{7}$,

"If you said, 'I am green and, actually, it is going to cost us a lot more [money]', that probably would not fly [be accepted in our bank]. That is the commercial reality of an economic decision like that [sustainability practice]. So, the obstacle to that [sustainability practices] would be that [commercial reality]. But on the measurement thing, you are an accountant; I am an accountant, our goal is to find consistency, useful information and relevant information" (F25).

The above quote indicates the need to clarify the commercial reality of sustainability practices. It seems significant to question banks' commitments to $\mathrm{SD}$, sustainability in general. The primary focus of SD is not tied in with commercialism. The main ideology of this commercialism illustrates some aspects of financial capitalism. This form of capitalism seems to prioritize profitability issues to increase the legitimacy of organisational actions. However, the critique of this form of capitalism involves the absence of the main aspects of social and environmental profitability that could be achieved through many different ways such as the environmental saving of renewable energy practices, the revenues and saving from ecological and biodiversity practices. In addition, there are some possible benefits of social and environmental profitability that could be achieved to protect the environment for present and future generations (see Milne and Gray, 2013). The limits of environmental protection seem to be one of the main problematic themes of SD, especially in the context of business practices or actions that should be maintained in the main agenda of banking and business organisations. The process of considering these limits could be linked to Gray and Bebbington's (2001) questions that had been offered to identify (imagine) the framework of sustainable performance e.g. sustainability at what level of resolution and in what way. This

\footnotetext{
7 This comment was in response to being asked about practical obstacles to developing and applying social and environmental practices.
} 
argument would enrich the development of more organisational guidance on managing social and environmental business model within banks.

In relation to lending specifically for social, environmental and sustainability-oriented projects, it seemed the banks interviewed were in the process of developing their sustainability practices to account for the funding they have provided but also, increasingly, on the social and environmental impact of such lending,

"We are using key performance indicators and statistics to measure our sustainable performance. There are a couple of things here. I mean we can certainly provide statistics on things like, you know we have lent so many millions of dollars for energy efficiency. We have put so many millions of dollars into renewable energy. You know we can do statistics like that..... You know syndicated dollars for our own dollars and what is gone into support green projects for example. But if you ask us some fundamental questions about impact, how do we measure the impact of our financing? So if we did say a municipal programme for water supply, how many additional people have got hooked up to a clean water supply? That's something that we are in the process of developing" (F5).

These mechanisms of accountability, such as measuring the number of people who have benefitted from a sustainability water initiative, represent another level of re-embedding. Such accountability mechanisms can further assist in rebuilding societal trust. Indeed, the development of accountability mechanisms such as enhancing transparency was evident in many of the interview discussions. In addition to publicly produced reporting on social and environmental impacts and issues, other methods of transparency and accountability mentioned by interviewees included weekly meetings of the whole bank to discuss issues arising, as well as engaging with stakeholders at 'green' conferences.

The important role of the UNEP FI in driving sustainability initiatives and adherence to social and environmental lending criteria was also highlighted by our interviews. In addition to the 
Equator Principles, the focus on the UN's environment programme on financial institutions is having a demonstrable impact on banks' behaviour and approaches, as discussed below,

"UNEP FI is a specific activity of UNEP, focused on financial institutions and they have developed a bunch of criteria which define what a sustainable bank would do. A sort of bundle/portfolio approach to achieving sustainable finance - several mechanisms all working together but separately to drive sustainable lending and sustainable approaches to finance" (F5).

Indeed, one of our interviewees emphasised the importance of both UNEP FI and the Equator Principles in driving sustainability within the banking sector, due to the frameworks and governance they provide,

"We manage our sustainable practices through the governance structures and the frameworks that are already in place through the United Nations, through the Equator Principles and so on. So there are frameworks, the regional principles on human rights. There are frameworks that are already in place, it is just a question of continuing on the journey for these banks to make sure that they are managing all of their impacts through those frameworks" (F9).

Continuing the journey towards sustainability goals by following principles and continually improving performance in this area represents an important part of a dynamic process and suggests a dynamic approach to re-embedding: re-embedding does not simply happen with societal trust in banks being restored, but is, rather, the continuous path towards an improved and strengthened relationship of trust between banks and their stakeholders.

The interviewees generally discussed the development of governance around social, environmental and sustainability activities and $\mathbf{d s}$, indicating that in their view, corporate governance, good governance and value creation was inseparable from issues of sustainability. 


\subsection{Sustainability initiatives as risk management and re-embedding mechanisms}

Sustainability initiatives, especially it seems, external sustainability initiatives, were perceived by the interviewees as risk management mechanisms, implemented primarily, it seems, as a means of managing reputational risks that could arise due to potential reputational damage was a bank to be considered unsustainable. From a Becksian theoretical perspective (2010) our findings suggest that banks are developing initiatives as they are increasingly aware of societal concerns regarding climate change and social issues. These concerns are engendering societal expectations that banks and other financial institutions should be acting more responsibly and should be enacting SD. These societal expectations also represent significant reputational risks for banks that are not adopting sustainability initiatives. Further, there seems to have been a recent shift in societal attitudes towards issues relating to sustainability that has acted as another factor driving banks to develop sustainability initiatives. With reference to Giddens' framework (1991), sustainability initiatives represent re-embedding mechanisms, their implementation seeking to rebuild societal trust. Indeed, interviewees commented that there is an ongoing transformation in societal attitude concerning sustainability resulting in a rise in demand from their client base for financial services that take account of social and environmental issues as indicated in the following quote

"There is a massive demand at the moment for our services. There is a culture change going on. I mean we are inundated by depositors, who believe in the mission of our organisation. I think the sustainability movement is growing and ethical finance is growing as well with demand for social mainstream" (F14).

Connected to this culture change is the need for banks to demonstrate their commitment to society, to legitimise their actions and strategies through adopting sustainability initiatives, 
"I think, at the macro level, without sustainability the bank would not survive. So it is absolutely critical - but also corporate social responsibility is an important element of the bank. Maybe not in the 'immediate', the 'now' of the business, but certainly in terms of its reputation in the community and its standing in the community, it is taken very seriously" (F7).

This quotation resonates with Beck's (1997) comments that companies are now seen as either villains or heroes (see above), and the banks' evident desire to be perceived as the latter. Indeed, the same interviewee included reputational risk as one of the three main risks facing banks,

"The main challenges to the survival of any banking institution are centred in operational risk, reputational risk and credit risk" (F7).

It seems from our interview analysis that reputational risk management is partly if not wholly driving sustainability initiatives. However, in addition to risks from reputational damage, the interviewees also identified sustainability-related risks potentially arising from being in breach of environmental legislation. Indeed, one interviewee indicated that unless a bank perceives risk attached to sustainability issues they would be unlikely to pay such issues any attention,

"I think there needs to be a risk - I mean with all the environmental things, I think, they only look at it because they are worried about a fine. I think that's probably the main criteria for being more sustainable ... I think it's probably the only way because, generally, people will try to get away with what they can. So, I don't think banks are going to be sustainable just because they want to; they need to have an incentive to do so" (F8).

Another interviewee suggested that environmental issues would not be taken into account in banking decisions unless there was a reputational risk attached to their neglect, 
"I do not think that banks take in the environmental issues when they are making investments, banks, I do not think they consider that, unless it is a sensitive political issue which might make the investment less attractive. They would take that into account" (F16).

This quotation again underlines the reputational risk management motivation underlying the implementation of sustainability initiatives, as the interviewee mentions sensitive political issues that clearly could affect the bank's reputation.

In his risk society thesis, Beck refused to adopt a singular lens, instead of focusing on the intersection between 'the risk itself and public perception of it' (Beck 1992, P.55). This approach assists in the interpretation of our interview data in that the adoption and implementation of sustainability initiatives by the banks interviewed appears to be driven for the most part by potential risks arising from public perception of climate change and social factors: the risk of reputational damage to the banks if they do not implement sustainability initiatives.

\subsection{Sustainability initiatives as coping mechanisms}

There appeared to be a separation between the attitudes of our interviewees towards internal and external sustainability initiatives. Interviewees' views concerning external initiatives such as the adoption of the Equator Principles, as discussed above, tended to be more institutional, with less personal 'buy-in', and implementation being motivated by reputational risk management concerns. Where interviewees discussed internal sustainability initiatives and practices, they appeared to be more personally involved. It seemed that they were personally and individually committed to these initiatives, using the words 'we' and 'us' when discussing their implementation. Social and environmental awareness, and the escalating risks arising from irresponsible business practices, are engendering a shift in 
societal attitudes, but societal attitudes are reflected through employees in the banks themselves. Employees, as concerned and aware members of society, are also driving sustainability initiatives from the inside. Therefore, in addition to external pressures on banks to engage in SD and sustainable business practices, as well as to respond to external societal concerns, there are also internal drivers. Banks are not inanimate institutions but consist of, and depend on, the people who run them and the people who are employed by them. It is this intricate linkage to 'society' within institutions that is also engendering substantial change in attitude and practice. This thinking is in line with Giddens' predictions that a 'second wave' of response to the hazards posed by global warming, that involves, "...embedding it [climate change] in our institutions and in the everyday concerns of citizens" (Giddens, 2011, p.3). Further, we interpret these (mostly) internal sustainability initiatives as Giddensian coping mechanisms, assisting bank employees to believe they are reducing climate change risk, thereby creating a protective cocoon for themselves and rebuilding their ontological security. This is a misguided impression, as small-scale initiatives such as reducing paper consumption have little effect on global climate change, but day-to-day exercises such as using less water in the office, will make bank employees feel more secure, as they are 'doing something'. As coping mechanisms such initiatives were become embedded in the bank staff's everyday routines. For long-term effective approaches to sustainability, initiatives and strategies need to be genuinely embedded in the organisation and its employees. An example from our interviews where a sustainability initiative was implemented through engagement with the bank's employees is demonstrated by the following quotation,

“... We do have initiatives where, as a business, in our staff meetings we talk about things that we would like to do, that the staff generate. One of those was recycling, some years ago. So now if a member of staff comes up with a good idea we try and implement it" (F7). 
Again, this interviewee seems concerned about his bank. He is seeking to honour a genuine commitment to these sustainability initiatives, as seen from his self-proclaimed desire to 'do' sustainability at a 'deeper level'. Note the use of 'we' in the interviewee's discourse: these sustainability initiatives are seen as arising from the employees themselves, they are bought into them, they associate with them and they are not separating the initiatives from themselves. By taking ownership of these initiatives, we suggest they are using them as coping mechanisms in the face of immeasurable and unsettling climate change risk. Another interviewee appeared to have a deeply-rooted commitment to sustainability, and especially social, initiatives, in relation to the bank's culture and history,

“Our general social projects, that we are not just a money making-machine, we are socially aware and we are aware, in part, of our heritage. It is important for us to be seen not just as a moneymaking machine but to actually be a part of the community, certainly in the UAE, and enable us to take a leadership role within society in the UAE" (F15).

Further, banks' ethical policies are now incorporating social and environmental concerns such that these issues are effectively mandatory considerations for the organisations,

"The ethical policy is a policy which has existed for 20 years. It is been updated five times in that period. This policy has very strict guidelines that say that the bank will and would not finance, based on their activity. So on the ecological side, the environmental side, which is what you are interested in, it [the ethical policy] has got statements such as "We would not finance a business that is involved in the extraction of fossil fuels" (F6)

These findings contrast with earlier research that found a total absence of ethical discourse in investor-company engagement on climate change, with the discourse being subsumed in a risk-dominated discourse focused entirely on financial materiality (Solomon et al., 2011). 
Instead, we found evidence from the banks interviewed of consideration of emotional, ethical and ecological motivations for implementing sustainability initiatives. This suggests a shift among financial institutions towards a multi-motivational model, with banks embracing sustainability approaches for a range of reasons, rather than purely financial considerations: reducing reputational risk whilst simultaneously pursuing socially responsible objectives for the 'right' reasons.

\section{Eighths: Concluding thoughts}

Using Beck's risk society theory as a theoretical lens through which to interpret the interview data allows a number of concluding comments and suggestions to be made.

Our findings resonate with earlier research into institutional investors' attitudes towards climate change that found their engagement and dialogue with companies around climate change issues to be imbued with a risk discourse: their initiatives and actions were dominated by risk management motivations. The overriding motivation for banks to implement sustainability initiatives appears to be management of reputational risk, linked to an understanding that societal attitudes had shifted such that all institutions and organisations were now expected to pursue SD. However, we found some evidence that genuine change was afoot, with interviewees displaying deep, personal commitment to a sustainable approach, implementing social and environmental initiatives for more ethical rather than riskbased reasons. These rather different findings tended to involve internal sustainability initiatives, rather than external. From the perspective of Giddens' theoretical work, sustainability initiatives also represent a means of re-embedding, of rebuilding trust among banks' shareholders in the wake of the financial crisis and in response to the potentially catastrophic systemic risks associated with climate change and global warming. 
It seems that the banks are 'doing sustainability' in a manner similar to that encapsulated in an industrial society perspective rather than from a more advanced, late phases risk society perspective (Beck, 1999). They are attempting to control and manage sustainability issues in a similar way to the study of private climate change reporting found investors had effectively 'fallen prey to self-deception' that climate change represents a risk that can be managed and had therefore turned to seek to manage the unmanageable, hiding behind their comfortable financial view of the world where everything can be modelled (Solomon et al., 2011). Lastly, we suggest that the internal sustainability initiatives were interpreted, through Giddens' theoretical framework, as a means of coping with the risks of the high consequences of climate change, thereby assisting bank employees to recreate their protective cocoon and restore their shattered ontological security. 


\section{References}

Aklitar, S. (2007). Sustainability and Challenges. Economic Review, 9(10), 43-47.

Atkins, J. and Atkins, B. (2019). Around the World in 80 Species: Exploring the Business of Extinction, Routledge, UK.

Atkins, J. and Macpherson, M. (2019). "Developing a Species Protection Action Plan - An Integrated Approach for Taxonomies, Reporting and Engagement for the Financial Services Sector”, Concept Paper circulated at Investec Bank’s Natural Capital, Species Extinction and Sustainable Financial Markets Event, 30th May.

Baumgartner, R. J., and Ebner, D. (2010). Corporate sustainability strategies: Sustainability profiles and maturity levels. Sustainable Development, 18 (2). 76-89.

Beck, T., Demirgüç-Kunt, A., and Levine, R. (2010). Financial institutions and markets across countries and over time: The updated financial development and structure database. The World Bank Economic Review, 24 (1). 77-92.

Beck, U. (1987). The Anthropological Shock: Chernobyl and the Contours of the Risk Society. Berkeley Journal of Sociology. Vol. 32(1). 153 - 165.

Beck, U. (1992). Risk Society: Towards a New Modernity, London.

Beck, U. (1997). Sub-politics: ecology and the disintegration of institutional power", Organization and Environment, 10 (1). 52-65

Beck, U. (1999). World Risk Society. Blackwell Publishers, Cambridge.

Beck, U. (2007). Beyond Class and Nation: Refraiming Social Inequalities in a Globalised World. The British Journal of Sociology. Vol 58 (4).

Beck, U. (2009). World at Risk. Polity Press. Cambridge.

Beck, U., Giddens, A., Lash, S. (1994). Reflexive Modernization: Politics, Tradition and Aesthetics in the Modern Social Order. Stanford University Press. California. 
Berglof, E. (2011). A European perspective on the global financial crisis, Corporate Governance: An International Review, 19(5). 497-501.

Bihari, S. C. (2010). Green Banking-Towards Socially Resonsible Banking in India. Journal of Business Insights and Transformation, October, 4(1). 82-88.

Boiral, O. (2006). Global warming: should companies adopt a proactive strategy? Long Range Planning 39(3). 315-330.

Bryman, A. and Bell, E. (2007). Business Research Methods. 2nd Ed. Oxford, Oxford University Press.

Bryson, D., G. Atwal, A. Chaudhuri, and K. Dave. (2016). “Antecedents of Intention to Use Green Banking Services in India.” Strategic Change (25). 551-567.

Burgess, A., Wardman, J., Mythen, G. (2017). "Considerng risk: placing the work of Ulrich Beck in context", Journal of Risk Research, editorial, November.1-5.

Conyon, M., Judge, W. Q. and Useem, M. (2011). Corporate governance and the 2008-2009 financial crisis, Guest Editorial, Corporate Governance: An International Review, 19(5). 399404.

Coulson, A. B., (2009). How Should Banks Govern the Environment? Challenging the Construction of Action Versus Veto. Business Strategy and the Environment, 18(3). 149-161. Deepa, P., and D. C. Karpagam. (2018). “A Study on Customer's Awareness on Green Banking in Selected Public and Private Sector Banks with Reference to Tirupur." International Journal of Advanced Research and Development 3 (1). 58-63.

Delgado-Márquez, B. L., and Pedauga, L. E. (2017). Environmental behavior and MNEs: A strategy pulled by stakeholder engagement. Business Strategy and the Environment, 26(7). 927-939. 
Dell'Atti, S., Trotta, A., Iannuzzi, A. P., and Demaria, F. (2017). Corporate social responsibility engagement as a determinant of bank reputation: An empirical analysis. Corporate Social Responsibility and Environmental Management, 24(6). 589-605.

Englert, M. R., Koch, C., and Wüstemann, J. (2018). The effects of financial crisis on the organizational reputation of banks: An empirical analysis of newspaper articles. Business and Society, 1-35.

Fanasch, P. (2019). Survival of the fittest: The impact of eco-certification and reputation on firm performance. Business Strategy and the Environment, 28(4), 611-628.

Fombrun, C. J. (2005). A world of reputation research, analysis and thinking-building corporate reputation through CSR initiatives: Evolving standards. Corporate Reputation Review, 8(1). 7-12.

Forcadell FJ, Aracil E, Ubeda F.(2020). "Using reputation for corporate sustainability to tackle banks digitalization challenges", Business Strategy and the Environment, 1-13.

Forcadell, F. J., and Aracil, E. (2017). European banks' reputation for corporate social responsibility. Corporate Social Responsibility and Environmental Management, 24(1). 1-14. Gallego-Alvarez, I., and Pucheta-Martínez, M. C. (2019). Environmental strategy in the global banking industry within the varieties of capitalism approach: The moderating role of gender diversity and board members with specific skills. Business Strategy and the Environment, 347-360.

Giddens, A. (1987). Social Theory and Modern Sociology. Stanford University Press. California.

Giddens, A. (1990). The Consequences of Modernity. Stanford University Press. Stanford California.

Giddens, A. (1991). Modern and Self-Identity: Self and Society in the Late Modern Age. Blackwell Publishing. Cambridge. 
Giddens, A. (1992). The Transformation of Intimacy: Sexuality, Love, and Eroticism in Modern Societies. Stanford University Press.

Giddens, A. (1994). Living in a Post-Traditional Society. In Beck, U., Giddens, A., and Lash, S. (eds), Reflexive Modernisation: Politics, Tradition and Aesthetics in the Modern Social Order. 56 - 109. Polity. Cambridge England.

Giddens, A. (1998). Risk Society: The Context of British Politics. In Franklin, J. (eds). The Politics of Risk Society Order. Polity Press. Cambridge.

Giddens, A. (1999). Risk and Responsibilities. The Modern Law Review. Vol. 62(1). 1 - 10.

Giddens, A. and Pierson, C. (1998), Conversations with Anthony Giddens: Making Sense of Modernity, Blackwell, Oxford.

Giddens, A. (2009). Sociology (Sixth Edition). Cambridge, Policy Network: Polity.

Giddens, A. (2011). The Politics of Climate Change, Polity Press, Cambridge, UK.

Gray, R. and Bebbington, J. (2001). Accounting for the Environment. 2nd Ed. London: SAGE Publications Ltd.

Gray, R. and Milne, M. (2002). Sustainability Reporting: Who's Kidding Whom. Chartered Accountants Journal of New Zealand, 81(6). 66-70.

Hubbard, G. (2009). Measuring organizational performance: Beyond the triple bottom line. Business Strategy and the Environment, 18(3), 177-191. https://doi.org/10.1002/bse.564 Jabbour, LS, Jabbour, CJC. (2009). Are supplier selection criteria going green? Case studies of companies in Brazil. Industrial Management and Data Systems 109(4). 477-495.

Jeucken, M. (2004), Sustainability in Finance- Banking on the Planet. Netherland: Eburon Academic Publishers.

Jeucken, M. (2010). Sustainable finance and banking: The financial sector and the future of the planet. Routledge. 
Kapoor, N., Jaitly, M., and Gupta, R. (2016). “Green Banking: A Step Towards Sustainable Development." International Journal of Research in Management, Economics, and Commerce 6 (7). 69-72.

Kay, J. (2012). The Kay Review of UK Equity Markets and Long-Term Decision Making, Final Report, July.

Kim, G., Shin, B., and Lee, H. G. (2009). Understanding dynamics between initial trust and usage intentions of mobile banking. Information Systems Journal, 19(3). 283-311.

Lai, A., Melloni, G., and Stacchezzini, R. (2016). Corporate sustainable development: Is 'integrated reporting' a legitimation strategy? Business Strategy and the Environment, 25(3). $165-177$.

Lindenberg, N., and Volz, P. (2016). Green Banking Regulation-Setting out a Framework. UN City of Bonn: German Development Institute.

Macve, R. and Chen, X. (2010). The "Equator Principles": A Success for Voluntary Codes?. Accounting, Auditing and Accountability Journal, 23(7). 890-919.

Masukujjama, M., Siwa, C., Mahmu, M., and Alam, S. (2016). "Bankers' Perception of Green Banking: Learning From the Experience of Islamic Banks in Bangladesh.” Malaysian Journal of Society and Space, 12(2).

Mehedi,S., Kuddus, M., and Maniruzzaman, M. (2017). “The Identification of Bankers' Perception Toward Indicators For The Adoption Of Green Banking In Bangladeshi Scheduled Commercial Banks.” Journal of Internet Banking and Commerce 22 (2). 1-18. McElroy, M. and Engelen, J. V. (2012). Corporate Sustainability Management, 1st Ed. New York: Earthscan.

Miles, M. B., Huberman, M. and Saldaña, J. (2014). Qualitative Data Analysis; A Methods Sourcebook. 3rd Ed., SAGE Publications Inc . 
Milne, M. J. and Gray, R. (2013). W(h)ither Ecology? The Triple Bottom Line, the Global Reporting Initiative, and Corporate Sustainability Reporting. Journal of Business Ethics, $118(1), 13-29$.

Miras-Rodríguez, M., Carrasco-Gallego, A., and Escobar-Pérez, B. (2015). Has the CSR engagement of electrical companies had an effect on their performance? A closer look at the environment. Business Strategy and the Environment, 24(8). 819-835.

Moxey, P. and Berendt, A. (2008). Corporate governance and the credit crunch, ACCA Discussion Paper, November, ACCA, London.

Nienaber, A. Hofeditz, M., and Searle, H. (2014). Do we bank on regulation or reputation? A meta-analysis and meta-regression of organizational trust in the financial services sector. International Journal of Bank Marketing, 32(5). 367-407.

Orlitzky, M., Schmidt, F. L., and Rynes, S. L. (2003). Corporate social and financial performance: A meta-analysis. Organization Studies, 24(3). 403-441.

Ortiz-de-Mandojana N, and Bansal, P. (2015). The long-term benefits of organizational resilience through sustainable business practices. Strategic Management Journal 37(8). 16151631.

Park, S. B. (2018). Multinationals and sustainable development: Does internationalization develop corporate sustainability of emerging market multinationals? Business Strategy and the Environment, 27(8). 1514-1524.

Pérez, A., and del Bosque, I. R. (2015). How customer support for corporate social responsibility influences the image of companies: Evidence from the banking industry. Corporate Social Responsibility and Environmental Management, 22(3). 155-168.

Prakash Pillai, R., and Praveen Raj, D. (2019). "Perspective and Usage Patterns of Green Banking Services: A Cross-Sectional Analysis of Customers From Selected Banks in Kerala.” Research Review International Journal of Multidisciplinary 4 (2). 285-292. 
Prerana, S. and Arup, R. (2020). “A Scientometric analysis of literature on Green Banking”, Journal of Sustainable Finance and Investment

Raut, R., Cheikhrouhou, N., and Kharat, M. (2017). "Sustainability in the banking industry: A strategic multi-criterion analysis", Business Strategy and the Environment, Volume 26, Issue 4.

Relaño, F. (2011) "Maximizing social return in the banking sector”, Corporate Governance: The International Journal of Business in Society, 11(3).

Ruiz, B., Esteban, A., and Gutierrez, S. (2014). Determinants of reputation of leading Spanish financial institutions among their customers in a context of economic crisis. BRQ Business Research Quarterly, 17(4). 259-278.

San-Jose, L., Retolaza, J. L. and Gutierrez-Goiria, J. (2011). Are Ethical Banks Different? A Comparative Analysis Using the Radical Affinity Index. Journal of Business Ethics, (100). 151-173.

Sarma, P. and Roy, A. (2020). A Scientometric analysis of literature on Green Banking (1995-March 2019), Journal of Sustainable Finance and Investment, DOI: 10.1080/20430795.2020.1711500

Scholtens, B. (2009). Corporate social responsibility in the international banking industry. Journal of Business Ethics, 86(2). 159-175.

Scholtens, B. (2017). Why finance should care about ecology. Trends in Ecology and Evolution, 32(7). 500-505.

Scholtens, B. and Dam, L. (2007) "Banking on the Equator: Are banks that adopted the Equator Principles different from non-adopters?”, World Development, (35).1307-1328.

Shen L, Olfat L, Govindan, K., Khodaverdi, R., and Diabat, A. (2012). A fuzzy multi criteria approach forevaluating green supplier's performance in green supply chain with linguistic preferences. Resources, Conservation and Recycling 74(1). 170-179. 
Solomon, J. F., Solomon, A. Joseph N. L. and Norton, S. D. (2011). "Private Climate Change Reporting: A Discourse of Risk and Opportunity?", Accounting, Auditing and Accountability Journal, 24(8).1119-1148.

Solomon, J. (2020, forthcoming). Corporate Governance and Accountability, John Wiley and Sons Inc., 5th edition, Chichester, UK.

The Equator Principles (2014). The Equator Principles Implementation Note, It could be accessed via https://equator-principles.com/ep-association-news/implementation-note/ (Accessed on 16 ${ }^{\text {th }}$ June 2020)

Torelli, R., Balluchi, F., and Lazzini, A. (2019). Greenwashing and environmental communication: Effects on stakeholders' perceptions. Business Strategy and the Environment, 407-421.

UNEP FI, (2011). United Nations Environmental Programme Finance Initiative. [Online] Available at: https://www.unepfi.org/[Accessed 14th October 2019].

Walker, D. (2009). A Review of Corporate Governance in UK Banks and other Financial Industry Entities, The Association of Chartered Certified Accountants (ACCA), The Walker Review Secretariat, London 26 NovemberOctober .

Yip, A. W., and Bocken, N. M. (2018). Sustainable business model archetypes for the banking industry. Journal of Cleaner Production, 174, 150-169. 
Table 1

Interviewees' details and coding

\begin{tabular}{|c|c|}
\hline Interviewee's Code & Interviewee's role in the institution \\
\hline F1 & Head of Green Investment Projects in Non-efficiency sector \\
\hline F2 & $\mathrm{CFO}$ \\
\hline F3 & Executive manager administration and HR \\
\hline F4 & Senior environment advisor \\
\hline F5 & Deputy head (loan syndications) \\
\hline F6 & Ethics advisor \\
\hline F7 & Country head, UK and Jersey \\
\hline F8 & Manager, loan syndication and sales \\
\hline F9 & Head of CSR \\
\hline F10 & Communications officer \\
\hline F11 & Business development manager \\
\hline F12 & Sales department \\
\hline F13 & Social impact advisor \\
\hline F14 & Head of communications \\
\hline F15 & Financial controller \\
\hline F16 & Head of treasury \\
\hline F17 & Chief financial and operating officer \\
\hline F18 & Head of marketing \\
\hline F19 & Head of customer strategy \\
\hline F20 & Research and development \\
\hline F21 & Relationship manager \\
\hline F22 & Relationship manager \\
\hline F23 & Head of environment \\
\hline
\end{tabular}




\begin{tabular}{|c|c|}
\hline Interviewee's Code & \multicolumn{1}{|c|}{ Interviewee's role in the institution } \\
\hline F24 & Head, sustainability strategy and community investment \\
\hline F25 & Facilities services manager \\
\hline Total & $\mathbf{2 5}$ interviewees (757 digital minutes $\approx \mathbf{1 2 . 3 7}$ hours) \\
\hline
\end{tabular}




\section{First: Introduction}

Societal trust in banks has collapsed as a result of excessive risk taking, poor structures for executive remuneration, inadequate risk management, unethical behaviour and poor social responsibility during the global financial crisis (Conyon et al., 2011; Kay Review, 2012; Ruiz et al., 2014; Solomon 2020; Walker Review, 2009). One only has to consider the bailout of banks considered 'too big to fail' (Conyon et al., 2011) to appreciate why society's faith and trust in banks has been rocked (Solomon, 2020). Berglof (2011) concluded that the financial crisis would refocus banks' attention on risk and risk management. Indeed, the destruction of banks' reputations following the global financial crisis has been well-documented in the academic literature (Dell'Atti et al., 2017; Englert et al., 2018; Forcadell and Aracil, 2017).

In addition to the collapse in trust and reputation arising from the financial crisis, banks are also witnessing the alienating effects of dis-embedding ${ }^{1}$ mechanisms, such as increased online banking, the closure of physical banks in towns and cities, the rise of call centres at the other side of the world from clients/customers, all of which represent abstract systems ${ }^{2}$ that create time-space distanciation. Such systems rely on societal trust at a time when trust in banks and in financial institutions generally is at an all-time low. The process of replacing face to face financial systems with 'faceless' commitments (Giddens, 1990; 1991) makes it harder for society to trust banks and other institutions. This need for trust in today's financial banking systems, combined with the collapse of societal trust arising from the financial crisis, has created an urgent need for banks to rebuild trust among their stakeholders and reinstate

\footnotetext{
1 Dis-embedding is defined as the 'lifting out' of social relationships from local contexts and their recombination across indefinite time/space distances (Giddens, 1991).

2 In Giddensian sociological language, abstract systems refer to symbolic tokens and expert systems, where symbolic tokens are defined as media of exchange that have standard value and are thus interchangeable across an indefinite variety of contexts (such as money or funds), and expert systems are defined as systems of expert knowledge, of any type, depending on rules of procedure transferable from individual to individual (Giddens, 1991). Expert systems can be interpreted as banking and financial systems.
} 
their reputations. The Kay Review raised this and provided a way forward for banks and other financial institutions (Kay Review, 2012).

As well as addressing reputational damage from the global financial crisis, banks face increasing challenges associated with climate change and related risks, and green/sustainable banking strategies can assist banks in restoring reputation (Dell'Atti et al., 2017; Englert et al., 2018; Forcadell and Aracil, 2017; Gallego-Alvarez and Pucheta-Martinez, 2019; Pérez and del Bosque, 2015). A sustainable approach to business represents an effective means of enhancing reputation as sustainability initiatives can assist in rebuilding stakeholder confidence (Fombrun, 2005; Forcadell et al., 2020). From a sociological perspective, sustainability initiatives, we suggest, represent re-embedding ${ }^{3}$ mechanisms, that can enhance societal trust in banking systems. Further, enhanced reputation can lead to higher levels of trust as it signals greater credibility (Nienaber et al., 2014).

Developing and implementing sustainability initiatives and practices is one way that organisations can enhance their reputation (Miras-Rodriguez et al., 2015; Delgado-Marquez and Padauga, 2017; Fanasch, 2019; Kim et al., 2009; Lai et al., 2016; Orlitzsky et al., 2003; Park, 2018; Torelli et al., 2019).

This paper seeks to fill the research gap by exploring the application of sustainability practices in relation to banks' implementation of sustainability initiatives such as the Equator Principles, through extensive interviews with representatives from leading banks based in the $\underline{\text { UK. Further, we interpret the empirical data through a theoretical framework around risk and }}$ risk management, deriving from sociology, especially the works of Giddens and Beck.

\footnotetext{
${ }^{3}$ The online Oxford Reference defines re-embedding as, "New forms of social relations, communities, and politics (see globalization) arising alongside a decline in traditional forms of social cohesion", https://www.oxfordreference.com/view/10.1093/oi/authority.20110803100410665
} 


\section{Second: Literature review:}

The literature review surveys prior studies in the following four main themes. Theme One provides a review of sustainable banking, green banking and the Equator Principles. Theme Two theorising banking sustainability initiatives through sociological and financial frameworks. Theme Three reviews ecological risks: dis-embedding, re-embedding, coping mechanisms and ontological security. Theme four analyses trust and risk: sustainability initiatives as a mean of restoring societal trust.

\section{Second2.1 Theme one: A review of sustainable banking, green banking and the Equator \\ Principles}

As the world continues to witness unprecedented anthropogenic climate change and its impact on societies and biodiversity, attention is turning increasingly to the finance industry to encourage banks, institutional investors, businesses and the accounting firms to incorporate 
social environmental and sustainability concerns into their decision-making and strategies (Solomon, 2020; Scholtens, 2017; Atkins and Macpherson, 2019; Atkins and Atkins, 2019). Such high consequence risks are an intrinsic part of $21^{\text {st }}$ century societies, being “...risks deriving from the globalised character of the social systems of modernity", as, "...nature, ...has in a certain sense come to an 'end' - as a result of domination by human beings - the risks of ecological catastrophe form an inevitable part of our horizon of day-to-day life" (Giddens, 1991, p.4). Indeed, Giddens considers climate change to constitute a fundamental threat to the future of global industrial civilisation (Giddens, 2009).

Globally, organizations are seeking to balance environmental, social and economic performance through sustainable development (SD hereafter) practices (Boiral, 2006; Jabbour and Jabbour, 2009; Hubbard, 2009; Baumgartner and Ebner, 2010; Shen et al., 2012; Ortizde-Mandojana and Bansal, 2015; Raut et al., 2017; Ozbekler and Ozturkoglu, 2020). Indeed, the social and environmental impacts of banks and other financial institutions have been recognised for some time as significant factors contributing to effective corporate governance (Coulson, 2009). The indirect impacts of banking on the environment are substantial and therefore they have an important role to play in SD through implementing sustainability initiatives (Beck et al., 2010; Yip and Bocken, 2018; Forcadell et al., 2020).

In the area of banking and sustainability, there is a growing literature focusing on 'sustainable banking' (Aracil, 2021), to vivid societal debate around the role of banks in the advancement toward sustainability. It involves which includes research into environmental protection through banks' investment in goods and services (Lindenberg and Volz, 2016). Indeed, there are two areas of sustainable and green banking that have attracted research interest: firstly, banks' internal initiatives, such as reducing paper usage and waste, and secondly, external 
initiatives, involving how the banks choose to invest funds (Sarma and Roy 2019). Some of the prior literature has focused on the advantages and disadvantages of green banking (Kapoor, Jaitly, and Gupta 2016). Various studies have considered the attitudes of bankers (Masukujjama et al. 2016; Mehedi, Kuddus, and Maniruzzaman 2017). Other research has concentrated on banking clients (Bryson et al. 2016; Prakash Pillai and Praveen Raj 2019; Deepa and Karpagam 2018), while some have studied penetration among the bankers.

'Green Banking' has evolved that seeks to limit banks' climate change impacts, at the same time investing in environmental goods and services (Lindenberg and Volz, 2016). One only has to consider recent media coverage of pressures from activist environmental Nonegovernmental Organisations (NGOs hereafter) on banks and financial institutions to appreciate the growing societal voice, for example the recent forced closures of Barclays branches in response to Greenpeace action. ${ }^{4}$ In recent years, banks have been responding to calls for greater accountability in relation to sustainability, and especially environmental issues, in primarily two ways: internally, by introducing social and environmental initiatives such as recycling and waste reduction, and; externally, by developing and applying social and environmental criteria to their lending decisions (Sarma and Roy, 2019). This second category of initiatives represents in part a response to the establishment of global principles and guidelines such as the Equator Principles. The role of the banking sector in allocating funds affords banks the potential to influence companies and organisations generally to become more sustainable and to pay greater attention to social and environmental considerations (Jeucken, 2010).

The introduction of the Sustainable Development Goals (SDGs hereafter) by the United Nations (UN hereafter) is driving governments and organisations across all sectors to adopt proactive measures and initiatives to address the challenges posed by the 17 SDGs. Such

${ }^{4}$ See article on the BBC website entitled, "Climate Change: Greenpeace Stops Barclays from Opening Branches" at https://www.bbc.co.uk/news/business-51702865 Accessed on $2^{\text {nd }}$ March 2020 
pressures were originally designed on a voluntary basis to manage these considerations in more effective and transparent sustainability principles (Macve and Chen, 2010). They aim to explore how business-organisations could use accounting tools and practices to apply sustainability principles to manage the main imperatives of SD. These imperatives involve a set of different dimensions to ensure fair and equal allocation of resources and opportunities between current and future generations/stakeholders (Gray and Milne, 2002). The effective management of these dimensions requires sensible considerations of some business imperatives e.g. fairness, accountability and ethical responsibilities (Grubnic, et al., 2015). Moreover, these imperatives involve incorporating climate change; ecological biodiversity, earbon emissions; human rights issues; global water shortage problems, and income and gender equality into core business activities. The determination of the needs of future stakeholders (generations) involve some measurement challenges and difficulties to predict these future needs and expectations (McElroy and Engelen, 2012). These developments are occurring across all sectors including the financial industry, with initiatives such as the Equator Principles being implemented by banks and other financial institutions. Despite these developments, the banking sector has been relatively under-researched in the area of SD, in comparison to other sectors (Raut et al., 2017). We seek to address this relatively under researched research gap.

The Equator Principles are one of the most significant external sustainability initiatives that banks around the world can engage_(Contreras, 2019). They represent a risk management framework, adopted by financial institutions, for determining, assessing and managing environmental and social risk in project finance (Equator Principles, 2014). They are perceived as a risk management approach (Abb et al., 2017). The Equator Principles are primarily intended to provide a minimum standard for due diligence to support responsible risk decision-making. The Principles apply globally, to all industry sectors and to four 
financial products: project finance, advisory services, project related corporate loans and bridge loans. The Equator Principles Association is the unincorporated association representing the member Equator Principles Financial Institutions (EPFIs hereafter) and Associates whose objective is the management, administration and development of the Equator Principles (Equator Principles, 2014). This umbrella Association was formed on 1 July 2010 with the aim of ensuring long-term viability and ease of management of the member EPFIs and Associates (ibid). An EPFI is a financial institution which has adopted the Equator Principles in accordance with the procedures in these rules, is active in project finance and whose name appears as an EPFI on the list of EPFIs and Equator Principles working groups. Each EPFI shall introduce and implement its own internal social and environmental risk management policies, procedures and standards in order to comply with the Equator Principles. All EPFIs have to apply all the principles to all new projects over $\$ 10 \mathrm{~m}$ from the date of adoption. The objectives of the Equator Principles are to: Promote and encourage the adoption of the Principles by more financial institutions; Promote and encourage the implementation of the Principles by the EPFIs and Associates in a manner eonsistent with good international banking practice and all applicable law and that offers reasonable consistency of approach; Develop the Principles as the EPFIs and Associates consider appropriate, having regard to developments in international practice, the evolution of sustainability standards, and the practices and the views of stakeholders; Maintain contact and share expertise with international financial institutions and other bodies who have developed their own social and environmental standards (Equator Principles, 2014). The adoption of the Equator Principles is open to any financial institution that meets the relevant adoption requirements and agrees to meet the on going reporting requirements. Adoption by a financial institution is voluntary but once such adoption has been made, the 
adopting entity must take all appropriate steps to implement and comply with the Equator Principles (Equator Principles, 2014).

Third2.2 Theme Two: Theorising banking sustainability initiatives through sociological and financial frameworks

The Equator Principles have become the financial industry standard for environmental and social risk management in project finance in some countries (Scholtens and Dam, 2007). Financial institutions adopt the Equator-Principles to ensure that the projects they finance are developed in a socially responsible manner and reflect sound environmental management practices. By doing so, negative impacts on project-affected ecosystems and communities should be avoided where possible, and if unavoidable, should be reduced, mitigated and/or compensated for appropriately. Adopters believe that the adoption of, and adherence to, the Principles offer significant benefits for themselves, and for their borrowers and local stakeholders through their borrowers' engagement with locally affected communities (Ibid). Adopters should be able to better assess, mitigate, document and monitor the credit and reputation risk associated with financing development projects. Additionally, the collaboration and learning on broader policy application, interpretation and methodologies between adopters, and with their stakeholders, helps knowledge transfer, learning and best practice development (Macve and Chen, 2010). The adopters' role as financiers affords them opportunities to promote responsible environmental stewardship and socially responsible development.developing sustainable criteria into their lending processes in order to reduce corporate sustainability risk (Kyriakos, 2021).

The relevant thresholds and criteria for their application is described in detail in the Scope section of the Equator Principles EPFIs commit to implementing the Principles in their internal environmental and social policies, procedures and standards for financing projects and will not provide project finance or project related corporate loans to projects where the 
elient will not, or is unable to, comply with the Principles. While they are not intended to be applied retroactively, EPFIs apply them to the expansion or upgrade of an existing project where changes in scale or scope create significant environmental and social risks and impacts, or significantly change the nature or degree of an existing impact.

Recent research shows that 94 EPFIs in 37 countries have officially adopted the Equator Principles, covering many international project finance debt in emerging markets (Equator Principles, 2014). The Principles have increased the attention and focus on social/community standards and responsibility, including robust standards for indigenous peoples, labour standards, and consultation with locally affected communities within the project finance market. They have also promoted convergence around common environmental and social standards. Multilateral development banks, including the European Bank for Reconstruction and Development, and some credit agencies through the Organisation for Economic $\mathrm{Co}$ operation and Development (OECD) are increasingly drawing on social and environmental standards as the Principles.

Another series of external sustainability initiatives include the shared effort to promote responsible environmental and social management practices in the financial sector and banking industry from The United Nations Environmental Programme Finance Initiative (UNEP FI hereafter). These initiatives have provided a platform for engagement with a broad range of interested stakeholders, including non-governmental organisations (NGOs), clients and industry bodies (UNEP FI, 2018).

Sociologists have sought to understand and theorise shifts in societal attitude associated with the emergence and increasing awareness of global threats to people and the planet for several decades. Ulrich Beck and Anthony Giddens, German and British sociologists respectively, have been significant in contributing to this understanding. Beck's (1992) risk society thesis built upon the characteristics of modernity (Giddens, 1990; 1991), identifying risk as a 
primary factor shaping society, institutions, politics and individual life choices. Beck defined risk society as, "a systematic way of dealing with hazards and insecurities induced and introduced by modernisation itself (Beck 1992:21)". Further, Giddens defined risk society as, "...a society increasingly preoccupied with the future (and also with safety), which generates the notion of risk," (Giddens and Pierson 1998, p.209). Altering financial systems and institutions such as banking is essential if the world is to adapt to impending climate change risks and alter the path, as, “... there has to be a profound restructuring of financial markets themselves and of banking" (Giddens, 2011, p.150).

\section{Fourth 2.3 Theme Three: Ecological risks: dis-embedding, re-embedding, coping mechanisms and ontological security}

One focus of Giddens' and Beck's work has been the ecological dimension of the risk society, as they perceived that humans' impact on the natural environment was affecting society at a deep level through the catastrophic risks faced by environmental degradation. Beck (1997) suggested that the way in which institutions were organised was not appropriate for the effective management of risk in a risk society. In the face of severe ecological problems, companies fall into either, "... the role of villain and poisoner, or ... the role of the hero and helper and celebrate this publicly.... "(Beck, 1997, p.61).

Giddens, in The Politics of Climate Change (Giddens, 2011) explored the unprecedented challenges faced by humans and capitalism arising from anthropogenic global warming and related effects. Beck (1997) described two constellations in the ecological conflict. One is characterised by confrontation, where polluter industries and affected groups confront each other. He explained that this constellation only begins to change when a second emerges where external interested parties get involved and the collaboration between polluters and 
victims which covers up the 'truth' starts to disintegrate. This happens as the industry recognises it is part of a risk society. Accountability for the emergence of high consequence risks and their impact is difficult to pinpoint due to chains of inter-related responsibility. It is almost impossible in our society, which is characterised by complicated webs of inter-linked accountability, to attribute blame or responsibility to anyone source. Scientific proof of linkage between cause and effect relating to risk analysis is being used as a means of dismissing risks. Beck also suggested that by insisting on scientific proof of causality, companies were able to escape accountability.

"By turning up the standard of scientific accuracy, the circle of recognised risks justifying action is minimized, and consequently, the scientific license is implicitly granted for the multiplication of risks. To put it bluntly: insisting on the purity of the scientific analysis leads to the pollution and contamination of air, foodstuffs, water, soil, plants, animals and people. What results then is a covert coalition between strict scientific practice and the threats to life encouraged or tolerated by it" (Beck, 1992, p.62).

The sustainability-related risks associated with business activity have many characteristics described by Beck (1992) and Giddens (1991). Firstly, the risks in contemporary society differ from risks in previous eras as they are invisible and difficult to detect. For example, radiation or pollutants in farmed produce are not detectible to the nose or eye, only their effects are felt. Another characteristic of risks in the situation of late modernity is that their consequences will be devastating for communities, the environment or biodiversity. They are, in Giddens' (1991) terms, 'high consequence' risks. The emergence of high consequence risks, especially social, environmental and sustainability risks has been highlighted as a societal trend (Giddens, 1991; Beck, 1992). This proliferation of high consequence risks has posed 
problems for society and especially for companies, who have been held increasingly accountable for their creation. ${ }^{5}$ Beck (1997) focused specifically on ecologically-derived risks and their effects on society, institutions and politics. The awareness of high consequence risks which represent dangers from which no one can be completely free has now become part of individuals' 'umwelt', the cocoon of relevance and normalcy with which individuals surround themselves in order to place themselves in the world (Goffman, 1971). Giddens (1991) defined an individual's protective cocoon as the mantle of trust that makes possible the sustaining of a viable Umwelt. This trust incorporates an attempt by individuals to come to terms with high consequence risk, either by accepting them, actively trying to reduce them (by recycling, for example) or by giving up worrying about them. The threat of climate change and the potentially apocalyptic implications arising from human impacts on the planet, nature and the environment are threatening to people's ontological security, making them feel insecure in the face of high consequence risks.

Beck (1999) explains that risk in the era of the 'risk society' involves approaches aimed at foreseeing and controlling the future unintended consequences arising from human actions and states that the risks from modernisation are irreversible threats to people, flora and fauna (Beck, 1992). The growth of the media has also contributed greatly to the increase in awareness of risks, especially in the sustainability area. Giddens (1991) discussed the way in which the development of electronic media has contributed to the construction of a reflexive modernity.

A further characteristic of the risk society thesis is that people are so-overwhelmed by risk information that there is a tendency for them to stop caring (Beck, 1992). There is a general

\footnotetext{
${ }^{5}$ The emergence of high consequence risks represents the dark side of modernity, being created by the rapidity of social and technological change. The types of risk falling into this category arise from the 'human control of natural and social worlds' (Giddens, 1991, p.109). Specifically, Giddens (1990) sketched an array of high consequence risks including the growth of totalitarian power, the collapse of economic growth, nuclear conflict or large-scale warfare, and ecological decay or disaster. Clearly, sustainability risks arising from corporate activity represent a significant ingredient in the materialisation of these high consequence risks.
} 
state of apathy among members of society arising from a feeling of helplessness. People switch off to risks because it is not 'normal' to worry constantly about high consequence risks such as nuclear war, as this would detract from coping with the practical aspects of everyday life. There is a numbing effect on society of constantly listing dangers, which ereates apathy (Giddens, 1990). This also translates into feelings of 'engulfment' (Giddens, 1990 , p.193) where people feel so overwhelmed by the potential risks and consequences arising from global warming and climate change that they cannot cope and react by trying not to contemplate these consequences: another response is to develop coping mechanisms that ean help to restore their ontological security. Another aspect of the risk society is that all 7 social classes are affected by risks. Whereas previously there was a division whereby higher classes could avoid risks, they cannot avoid the high consequence risks now pervading the economy.

We suggest that from a risk society theoretical perspective, banks' sustainability initiatives represent forms of coping mechanism, by which bank employees can feel they are addressing sustainability and related ecological risks through implementing initiatives. Such initiatives were interpreted as a means of re-embedding, rebuilding relationships between banks, their clients and other stakeholders. Perceiving sustainability initiatives in this way also leads us to consider the trust dimensions of the risk society theoretical framework and how this will be interpreted in relation to banks' sustainability initiatives.

\section{Fifth2.4 Theme Four: Trust and Risk: Sustainability initiatives as a means of restoring societal trust}

One of the salient characteristics of the risk society has been identified as a loss of trust. However, the interpretation of the role of trust in a risk society differs from the work of Beck and Giddens. Whereas Beck considered that the monumental rise in societal risk in recent 
years has created a less trusting, confident society, characterised by societal anxiety, Giddens' view is somewhat different. Giddens (1990) considered that there is not necessarily a higher level of risk, but that society has become more reflexive. This increase in reflexivity has led to a decline in trust, which in turn has led society to be more anxious and more preoccupied with risks and their potential consequences. Again, reflexivity has been flagged up as a cornerstone of the risk society thesis, but there are various interpretations of the term and its implications (see, for example, Giddens, 1990, p.36).

From a Giddensian viewpoint, institutions face a crisis of trust, given the current trend in society to lose trust in institutions and organisations (Giddens, 1992). Further, sociologists have claimed that society is turning to counter-experts to replace the loss of confidence in traditional experts (Beck, 1992). Giddens (1990) explored the relationship between trust and risk. He examined the relationship between confidence and trust, suggesting that a distinction between the two has been made whereby trust should be understood specifically in relation to risk. He explains that,

"risk largely replaces what was previously thought of as Fortmna (fortune or fate) and becomes separated from cosmologies. Trust presupposes an awareness of circumstances of risk, whereas confidence does not. Trust and confidence both refer to expectations that can be frustrated or cast down (Giddens, 1990, pp30-31).

He then goes on to set down his theory of risk and trust as follows. Trust is linked with contingency rather than with risk. Trust always carries the connotation of reliability in the face of contingent outcomes. Giddens stated that risk and trust intertwine and that trust generally serves to reduce or minimise the dangers to which particular types of activity are subject. In other words, building and establishing trust represents, in the Giddensian risk society framework, a form of risk management. Restoring trust and building confidence is a way of managing risk and therefore reducing societal anxiety, countering a loss of ontological 
security. There are some circumstances in which patterns of risk could be institutionalised, within surrounding frameworks of trust (stock market investments, for example).

Preserving corporate image, managing impressions and maintaining a 'good' external reputation among stakeholders is an integral part of Beck's risk society, as he explains,

"Those who find themselves in the public pillory as risk producers refute the charges as well as they can, with the aid of a 'counter-science' gradually becoming institutionalised in industry, and attempt to bring in other causes and thus other originators. The picture reproduces itself. Access to the media becomes crucial. The insecurity within industry intensifies: no one knows who will be struck next by the anathema of ecological morality. Good arguments, or at least arguments capable of convincing the public, become a condition of business success. Publicity people, the argumentation craftsmen, get their opportunity in the organisation (Beck, 1992, p.32).

Although banks, like other organisations, are aware of the need to implement sustainability initiatives and introduce SD strategies and policies, the risks attached to the concept of sustainability was less clear. Banks implement sustainability initiatives in a state of nichtwissen (not knowing), a concept discussed in Beck's risk society thesis. What risks are these initiatives being introduced to manage? Climate change? Social inequalities? Are these social and environmental risks manageable? How are they manifesting themselves? Why and how are these initiatives going to 'manage' these risks? If there is little or no understanding of the risks being addressed by such initiatives, then why are they being introduced at all? The interviews discussed in this paper provide some appreciation of the motivations underlying their introduction.

We consider that sustainability initiatives represent re-embedding and risk management mechanisms, especially the large-scale external initiatives such as the Equator Principles as they are a means of rebuilding societal trust in the banking sector, at the same time seeking to 
manage the risks arising from climate change, including reputational risk. Further, we suggest that some sustainability initiatives represent coping mechanisms, providing bank employees with an impression that they are controlling or mitigating the overwhelming risks associated with climate change and restoring their ontological security, giving them an illusion of control in the face of global catastrophic climate risk.

\section{SixthThird: Research method}

For this study we conducted 25 semi-structured interviews with senior representatives of 16 small and medium-sized banks operating in the UK. The interviewees' details are presented in Table 1. The interview invitations were sent out to all the targeted interviewees via email and social media. Most of the targeted interviewees were accessed through the customer services department and call centres. Through the data analysis process, some direct quotes from the interview transcripts and collected documents have been used to refer to some issues that entail significant topics to present or argue. The level of significance was determined based on the interviewees' responses and perceptions toward the main research topics and questions. The interviewees' quotes were coded in random alphabetical characters in order to ensure the interviewees' anonymity and confidentiality as indicated in the interview consent forms that have been signed by all interviewees. In order to study sustainable finance, banks seemed the appropriate focus for the study as they represent one of the most significant groups of financial intermediaries in the economy to manage SD and support the transition plans for a green economy. We interviewed both mainstream banks and banks with social/environmental and/or charitable objectives.

Risk mitigation is one of the four functions of a bank, according to Jeucken (2004). Risk mitigation by banks can achieve a positive impact on society. Banks have an extensive and comparative advantage in the information held (as a result of the knowledge they have of 
economic sectors, regulations and market developments). Furthermore, banks transform the economic resources in terms of duration, value, spatial location, and risk (see Bihari, 2010; Jeucken, 2004 and (San-Jose, et al., 2011). So, they have an embedded influence on economic growth and the welfare of societies. Therefore, it can be argued that they have a social responsibility for their investment and financing decisions to support SD. Further, the UK banking sector includes some international banks involved in SD from an Islamic perspective (e.g. Al Rayan Bank and Qatar Islamic Bank- UK QIB). Confidence in the Islamic finance system emerges from what has been claimed to be the better understanding of sustainability supported by a complete and deep social ideology to operate more ethically and responsibly within society (Aklitar, 2007). Interestingly, the UK government established the world's first investment bank solely dedicated to greening the economy in 2011. The primary purpose of this initiative is to set the UK firmly on course towards a green and growing economy, and also delivering long-term sustainable growth. Therefore, the banking industry has drawn global attention in the last few years as one of the influential sectors in the economy in the field of SD (Bihari, 2010). These banks are suppliers of debt capital as well as being institutional investors in their own preferences, so the researchers want to explore the application of sustainability principles. Also, the banking sector could be seen as one of the main sectors that could be able to manage SD. The banking sector can accumulate detailed business experience of many economic sectors and markets. This accumulated experience is gained from their own lending, investment and operational activities. Furthermore, the United Nations established, in 1992, the UNFI EP Initiative (UNEP FI, 2011) ${ }^{6}$. This Initiative represents an international partnership between the United Nations

\footnotetext{
${ }^{6}$ The three main sectors of finance, banking, insurance and investment, are represented and brought together in this global partnership. In addition, UNEP FI develops selective collaborations, UN-driven and finance sectordriven, with other partner organizations, in order to increase awareness and raise support for critical SD activities. UNEP FI contributes the perspectives of financial institutions to the various United Nations and global activities on sustainable finance. UNEP FI's activities are embedded throughout many disciplines
} 
Environment Programme and the global financial sector. The main purpose of this initiative is to develop and manage linkages between sustainability and financial performance. Accordingly, it seems particularly relevant to explore how sustainability practices could be applied in the UK banking sector.

Thematic analysis was used to analyse the interviewees' practices as more than mere factors responding to the world (Miles, et al., 2014). This approach enables researchers to explore different realities around social or human activities, and permits them to understand the behavioural contexts in which interviewees are involved (ibid). Therefore, the power of the qualitative research method focuses on exploring the meaning of words rather than quantification in the collection and analysis of data (Bryman and Bell, 2007). These deliberations have been carefully considered in developing the semi-structured interview questions in order to achieve the main research objectives. The average length of interviews was 50 minutes. All interviews were recorded and transcribed. The transcriptions were analysed interpretively, drawing themes from the data and coding interviewees' utterances through reading and re-reading.

\section{Table 1}

Interviewees' details and coding

\section{SeventhFourth: Empirical research findings}

This section presents the findings from the interview analysis according to three overriding themes, namely: (i) the interviewees' attitudes towards the Equator Principles and other

specifically the work areas of Climate Change, Ecosystems Management, Energy Efficiency and Social Issues such as creating capacity building and the sharing of best practices; setting global standards and principles and engaging stakeholders, both public and private. For more information see http://www.unepfi.org/ (Accessed on 4th January 2017) 
external sustainability initiatives; (ii) sustainability initiatives as risk management and reembedding mechanisms, and; (iii) sustainability initiatives as coping mechanisms.

\subsection{Interviewee's attitudes towards the application of sustainability principles Most of}

the interviewees were generally aware of the Equator Principles and one provided us with an in-depth description of how they were implemented in practice by their bank,

"The Equator Principles are a voluntary set of standards for determining, assessing and managing social and environmental risk in project financing. We signed the Equator Principles, which are applied to all our projects irrespective of the USD10 million capital costs threshold. We are actively involved in a strategic review launched by the Equator Principles Association in October 2010 to determine the future of the Equator Principles and to encourage greater consistency in the application of the Equator Principles in our markets. Under the Equator Principles, Environmental and Social risks are classified as: low (Category C), medium (Category B) or high (Category A). We report annually on the number of advisory and lending mandates executed by [our bank]" (F24).

Another interviewee highlighted their bank's commitment to ensuring that all lending is strictly against social and environmental criteria,

"Well in terms of responsibility to our investment and lending decisions, all of our projects are screened by the environment and sustainability department. We will decide the appropriate steps in terms of both due diligence and structuring of the project, to ensure that the project meets our standards" (F4).

Another interviewee emphasised the importance of ensuring that companies fit lending criteria on social and environmental issues relating to the Equator Principles,

"Our major concern is to make sure that the companies that we are lending to actually fit the criteria that we set out to ensure that they are green and sustainable" (F12).

One interviewee mentioned the 'three pillars' applied to all investment or lending projects, 


\begin{abstract}
"Sustainability, coming at it from my perspective, I would say it's one of the key elements of the strategy of the bank. We have three key pillars, which every project is required to meet, and these are the tests of transition. How does the project contribute to the transition to market economy process? ... So when you ask about the responsibility in investment and lending decisions, everything is screened for its environmental and social impact. All of the operations we do" (F5).
\end{abstract}

Both of the above quotes suggest from a Becksian and Giddensian theoretical perspective that following the Equator Principles were interpreted as a means of conveying and assuring the trustworthiness of the banks' compliance with the sustainability lending criteria. In this way, these 'pillars' and lending criteria were seen as mechanisms of re-embedding societal trust in the banking sector in the face of global warming and climate change.

Interestingly, although aware of the Equator Principles, and the social and environmental issues covered by them, one interviewee seemed a little uncertain of their name,

"The bank is a member of - what do you call it Equator Principles. So, any transaction or project that the bank finances need to comply with the Equator Principles. So that covers all social and environmental aspects" (F8).

This suggests that even though the Principles are being applied to rebuild trust, interpreting the utterance through a Giddensian, there is a lack of 'buy-in' to this substantial external initiative. Perhaps the Equator Principles are more about managing reputational risk than a genuine attempt to rebuild and nurture societal trust, which is in line with a business case, or instrumental ethics scenario (Solomon, 2020). There was further evidence of an instrumental ethics approach to implementing sustainability lending initiatives, such as the Equator Principles. One interviewee did however underline the importance of also making financially feasible lending decisions, although this priority seemed to be a 'given' after the fulfilment of socially acceptable criteria were met, 
"We need to be convinced that there is a social return, otherwise we cannot lend, but we also need to be convinced that we are going to get our money back. Otherwise, also, we cannot lend" (F13).

A similar, instrumental ethics approach is enshrined in the following comment, from the senior financial officer from a mainstream bank,

"We have an obligation to produce a certain return for our shareholders, as does every other bank. So I think if you can be nice to the environment as well, then great, but if there are two competing options, one with a higher return than the other, then we would go with the higher return option" (F17).

It is interesting that this rather short-sighted and outdated view persists. Separating profit and return from sustainability was proven invalid through the growth and expansion globally of the responsible investment movement. Specifically, the significant shift in attitude among the institutional investment community from one where they perceived socially responsible investment to involve sacrificing financial returns for social returns, to one where they started to appreciate how financial and social returns can be positively related, an enlightened shareholder approach (Solomon, 2020). Sadly, members of the banking community continue to be blind to these linkages. Or do they? Indeed, the (obvious) need to focus on profits and profitability as well as on social and environmental concerns was, as would be anticipated, highlighted by interviewees, such as ${ }^{7}$,

"If you said, 'I am green and, actually, it is going to cost us a lot more [money]', that probably would not fly [be accepted in our bank]. That is the commercial reality of an economic decision like that [sustainability practice]. So, the obstacle to that [sustainability practices] would be that [commercial reality]. But on the measurement thing, you are an

\footnotetext{
${ }^{7}$ This comment was in response to being asked about practical obstacles to developing and applying social and environmental practices.
} 
accountant; I am an accountant, our goal is to find consistency, useful information and relevant information" (F25).

The above quote indicates the need to clarify the commercial reality of sustainability practices. It seems significant to question banks' commitments to SD, sustainability in general. The primary focus of SD is not tied in with commercialism. The main ideology of this commercialism illustrates some aspects of financial capitalism. This form of capitalism seems to prioritize profitability issues to increase the legitimacy of organisational actions. However, the critique of this form of capitalism involves the absence of the main aspects of social and environmental profitability that could be achieved through many different ways such as the environmental saving of renewable energy practices, the revenues and saving from ecological and biodiversity practices. In addition, there are some possible benefits of social and environmental profitability that could be achieved to protect the environment for present and future generations (see Milne and Gray, 2013). The limits of environmental protection seem to be one of the main problematic themes of SD, especially in the context of business practices or actions that should be maintained in the main agenda of banking and business organisations. The process of considering these limits could be linked to Gray and Bebbington's (2001) questions that had been offered to identify (imagine) the framework of sustainable performance e.g. sustainability at what level of resolution and in what way. This argument would enrich the development of more organisational guidance on managing social and environmental business model within banks.

In relation to lending specifically for social, environmental and sustainability-oriented projects, it seemed the banks interviewed were in the process of developing their sustainability practices to account for the funding they have provided but also, increasingly, on the social and environmental impact of such lending, 
"We are using key performance indicators and statistics to measure our sustainable performance. There are a couple of things here. I mean we can certainly provide statistics on things like, you know we have lent so many millions of dollars for energy efficiency. We have put so many millions of dollars into renewable energy. You know we can do statistics like that..... You know syndicated dollars for our own dollars and what is gone into support green projects for example. But if you ask us some fundamental questions about impact, how do we measure the impact of our financing? So if we did say a municipal programme for water supply, how many additional people have got hooked up to a clean water supply? That's something that we are in the process of developing" (F5).

These mechanisms of accountability, such as measuring the number of people who have benefitted from a sustainability water initiative, represent another level of re-embedding. Such accountability mechanisms can further assist in rebuilding societal trust. Indeed, the development of accountability mechanisms such as enhancing transparency was evident in many of the interview discussions. In addition to publicly produced reporting on social and environmental impacts and issues, other methods of transparency and accountability mentioned by interviewees included weekly meetings of the whole bank to discuss issues arising, as well as engaging with stakeholders at 'green' conferences.

The important role of the UNEP FI in driving sustainability initiatives and adherence to social and environmental lending criteria was also highlighted by our interviews. In addition to the Equator Principles, the focus on the UN's environment programme on financial institutions is having a demonstrable impact on banks' behaviour and approaches, as discussed below, "UNEP FI is a specific activity of UNEP, focused on financial institutions and they have developed a bunch of criteria which define what a sustainable bank would do. A sort of bundle/portfolio approach to achieving sustainable finance - several mechanisms all working together but separately to drive sustainable lending and sustainable approaches to finance" (F5). 
Indeed, one of our interviewees emphasised the importance of both UNEP FI and the Equator Principles in driving sustainability within the banking sector, due to the frameworks and governance they provide,

"We manage our sustainable practices through the governance structures and the frameworks that are already in place through the United Nations, through the Equator Principles and so on. So there are frameworks, the regional principles on human rights. There are frameworks that are already in place, it is just a question of continuing on the journey for these banks to make sure that they are managing all of their impacts through those frameworks" (F9).

Continuing the journey towards sustainability goals by following principles and continually improving performance in this area represents an important part of a dynamic process and suggests a dynamic approach to re-embedding: re-embedding does not simply happen with societal trust in banks being restored, but is, rather, the continuous path towards an improved and strengthened relationship of trust between banks and their stakeholders.

The interviewees generally discussed the development of governance around social, environmental and sustainability activities and $\mathbf{d s}$, indicating that in their view, corporate governance, good governance and value creation was inseparable from issues of sustainability.

\subsection{Sustainability initiatives as risk management and re-embedding mechanisms}

Sustainability initiatives, especially it seems, external sustainability initiatives, were perceived by the interviewees as risk management mechanisms, implemented primarily, it seems, as a means of managing reputational risks that could arise due to potential reputational damage was a bank to be considered unsustainable. From a Becksian theoretical perspective (2010) our findings suggest that banks are developing initiatives as they are increasingly 
aware of societal concerns regarding climate change and social issues. These concerns are engendering societal expectations that banks and other financial institutions should be acting more responsibly and should be enacting SD. These societal expectations also represent significant reputational risks for banks that are not adopting sustainability initiatives. Further, there seems to have been a recent shift in societal attitudes towards issues relating to sustainability that has acted as another factor driving banks to develop sustainability initiatives. With reference to Giddens' framework (1991), sustainability initiatives represent re-embedding mechanisms, their implementation seeking to rebuild societal trust. Indeed, interviewees commented that there is an ongoing transformation in societal attitude concerning sustainability resulting in a rise in demand from their client base for financial services that take account of social and environmental issues as indicated in the following quote

"There is a massive demand at the moment for our services. There is a culture change going on. I mean we are inundated by depositors, who believe in the mission of our organisation. I think the sustainability movement is growing and ethical finance is growing as well with demand for social mainstream" (F14).

Connected to this culture change is the need for banks to demonstrate their commitment to society, to legitimise their actions and strategies through adopting sustainability initiatives,

"I think, at the macro level, without sustainability the bank would not survive. So it is absolutely critical - but also corporate social responsibility is an important element of the bank. Maybe not in the 'immediate', the 'now' of the business, but certainly in terms of its reputation in the community and its standing in the community, it is taken very seriously" (F7).

This quotation resonates with Beck's (1997) comments that companies are now seen as either villains or heroes (see above), and the banks' evident desire to be perceived as the latter. 
Indeed, the same interviewee included reputational risk as one of the three main risks facing banks,

"The main challenges to the survival of any banking institution are centred in operational risk, reputational risk and credit risk" (F7)

It seems from our interview analysis that reputational risk management is partly if not wholly driving sustainability initiatives. However, in addition to risks from reputational damage, the interviewees also identified sustainability-related risks potentially arising from being in breach of environmental legislation. Indeed, one interviewee indicated that unless a bank perceives risk attached to sustainability issues they would be unlikely to pay such issues any attention,

"I think there needs to be a risk - I mean with all the environmental things, I think, they only look at it because they are worried about a fine. I think that's probably the main criteria for being more sustainable ... I think it's probably the only way because, generally, people will try to get away with what they can. So, I don't think banks are going to be sustainable just because they want to; they need to have an incentive to do so" (F8).

Another interviewee suggested that environmental issues would not be taken into account in banking decisions unless there was a reputational risk attached to their neglect,

"I do not think that banks take in the environmental issues when they are making investments, banks, I do not think they consider that, unless it is a sensitive political issue which might make the investment less attractive. They would take that into account" (F16).

This quotation again underlines the reputational risk management motivation underlying the implementation of sustainability initiatives, as the interviewee mentions sensitive political issues that clearly could affect the bank's reputation. 
In his risk society thesis, Beck refused to adopt a singular lens, instead of focusing on the intersection between 'the risk itself and public perception of it' (Beck 1992, P.55). This approach assists in the interpretation of our interview data in that the adoption and implementation of sustainability initiatives by the banks interviewed appears to be driven for the most part by potential risks arising from public perception of climate change and social factors: the risk of reputational damage to the banks if they do not implement sustainability initiatives.

\subsection{Sustainability initiatives as coping mechanisms}

There appeared to be a separation between the attitudes of our interviewees towards internal and external sustainability initiatives. Interviewees' views concerning external initiatives such as the adoption of the Equator Principles, as discussed above, tended to be more institutional, with less personal 'buy-in', and implementation being motivated by reputational risk management concerns. Where interviewees discussed internal sustainability initiatives and practices, they appeared to be more personally involved. It seemed that they were personally and individually committed to these initiatives, using the words 'we' and 'us' when discussing their implementation. Social and environmental awareness, and the escalating risks arising from irresponsible business practices, are engendering a shift in societal attitudes, but societal attitudes are reflected through employees in the banks themselves. Employees, as concerned and aware members of society, are also driving sustainability initiatives from the inside. Therefore, in addition to external pressures on banks to engage in SD and sustainable business practices, as well as to respond to external societal concerns, there are also internal drivers. Banks are not inanimate institutions but consist of, and depend on, the people who run them and the people who are employed by them. It is this intricate linkage to 'society' within institutions that is also engendering substantial change in 
attitude and practice. This thinking is in line with Giddens' predictions that a 'second wave' of response to the hazards posed by global warming, that involves, “...embedding it [climate change] in our institutions and in the everyday concerns of citizens" (Giddens, 2011, p.3). Further, we interpret these (mostly) internal sustainability initiatives as Giddensian coping mechanisms, assisting bank employees to believe they are reducing climate change risk, thereby creating a protective cocoon for themselves and rebuilding their ontological security. This is a misguided impression, as small-scale initiatives such as reducing paper consumption have little effect on global climate change, but day-to-day exercises such as using less water in the office, will make bank employees feel more secure, as they are 'doing something'. As coping mechanisms such initiatives were become embedded in the bank staff's everyday routines. For long-term effective approaches to sustainability, initiatives and strategies need to be genuinely embedded in the organisation and its employees. An example from our interviews where a sustainability initiative was implemented through engagement with the bank's employees is demonstrated by the following quotation,

“... We do have initiatives where, as a business, in our staff meetings we talk about things that we would like to do, that the staff generate. One of those was recycling, some years ago. So now if a member of staff comes up with a good idea we try and implement it" (F7).

Again, this interviewee seems concerned about his bank. He is seeking to honour a genuine commitment to these sustainability initiatives, as seen from his self-proclaimed desire to 'do' sustainability at a 'deeper level'. Note the use of 'we' in the interviewee's discourse: these sustainability initiatives are seen as arising from the employees themselves, they are bought into them, they associate with them and they are not separating the initiatives from themselves. By taking ownership of these initiatives, we suggest they are using them as coping mechanisms in the face of immeasurable and unsettling climate change risk. Another 
interviewee appeared to have a deeply-rooted commitment to sustainability, and especially social, initiatives, in relation to the bank's culture and history,

"Our general social projects, that we are not just a money making-machine, we are socially aware and we are aware, in part, of our heritage. It is important for us to be seen not just as a moneymaking machine but to actually be a part of the community, certainly in the UAE, and enable us to take a leadership role within society in the UAE" (F15).

Further, banks' ethical policies are now incorporating social and environmental concerns such that these issues are effectively mandatory considerations for the organisations,

"The ethical policy is a policy which has existed for 20 years. It is been updated five times in that period. This policy has very strict guidelines that say that the bank will and would not finance, based on their activity. So on the ecological side, the environmental side, which is what you are interested in, it [the ethical policy] has got statements such as "We would not finance a business that is involved in the extraction of fossil fuels" (F6)

These findings contrast with earlier research that found a total absence of ethical discourse in investor-company engagement on climate change, with the discourse being subsumed in a risk-dominated discourse focused entirely on financial materiality (Solomon et al., 2011). Instead, we found evidence from the banks interviewed of consideration of emotional, ethical and ecological motivations for implementing sustainability initiatives. This suggests a shift among financial institutions towards a multi-motivational model, with banks embracing sustainability approaches for a range of reasons, rather than purely financial considerations: reducing reputational risk whilst simultaneously pursuing socially responsible objectives for the 'right' reasons. 


\section{EighthsFifth: Concluding thoughts}

The collected empirical data provides significant contribution to sustainability and green banking literature for the following reasons. First, it shows how to Usinguse Beck's risk society theory as a theoretical lens through which-to interpret banks' behaviour in manging reputational risks and building the societal trust. Second, this paper demonstrates the views of senior bankers toward the implementation of sustainability initiatives at their core business activities. Third, othe interview data allows a number of concluding comments and suggestions to be made.

Our findings resonate with earlier research into institutional investors' attitudes towards climate change that found their engagement and dialogue with companies around climate change issues to be imbued with a risk discourse: their initiatives and actions were dominated by risk management motivations. The overriding motivation for banks to implement sustainability initiatives appears to be management of reputational risk, linked to an understanding that societal attitudes had shifted such that all institutions and organisations were now expected to pursue SD. However, we found some evidence that genuine change was afoot, with interviewees displaying deep, personal commitment to a sustainable approach, implementing social and environmental initiatives for more ethical rather than riskbased reasons. These rather different findings tended to involve internal sustainability initiatives, rather than external. From the perspective of Giddens' theoretical work, sustainability initiatives also represent a means of re-embedding, of rebuilding trust among banks' shareholders in the wake of the financial crisis and in response to the potentially catastrophic systemic risks associated with climate change and global warming.

It seems that the banks are 'doing sustainability' in a manner similar to that encapsulated in an industrial society perspective rather than from a more advanced, late phases risk society perspective (Beck, 1999). They are attempting to control and manage sustainability issues in 
a similar way to the study of private climate change reporting found investors had effectively

'fallen prey to self-deception' that climate change represents a risk that can be managed and had therefore turned to seek to manage the unmanageable, hiding behind their comfortable financial view of the world where everything can be modelled (Solomon et al., 2011). Lastly, we suggest that the internal sustainability initiatives were interpreted, through Giddens' theoretical framework, as a means of coping with the risks of the high consequences of elimate change, thereby assisting bank employees to recreate their protective cocoon and restore their shattered ontological security. There are two groups of implications of this paper that could benefit the professional practice and society. The first group of implications includes managerial implications that benefit business managers (bankers). The second group of implications involves the non-managerial implications that could benefit other stakeholders e.g. SD researchers and activists, customers, supervisory authorities, government, professional bodies, customers, and shareholders. The managerial implications involve the possibility of developing an internal (organisational) code of business practices to use sustainability initiatives to organise and manage the social and environmental activities of banking operations. This code would represent an internal organisational guide to manage reputational risks and rebuild the societal trust such as green lending and borrowing policy and commercialising social and environmental investments. In addition, this paper could be used to develop another organisational account to manage the organisational contribution to environmental enhancement and improvement. This account could involve the organisational impact on the less influential stakeholders who are negatively affected by environmental damage.

The second group of implications involves some practical benefits that could be delivered to $\underline{\text { sustainability initiatives setters and regulators to explore any future compulsory framework of }}$ sustainability reporting standards. It involves the practical considerations that should be 
raised and maintained in these initiatives such as the sustainability to manage sustainability risks. Furthermore, this paper could be used to build up the internal and external organisational capabilities (activities) to include the most significant imperatives of SD in the core business activities.

The theoretical implication reveals that sustainability initiatives are imbued with reputational risk management and also indicates that some sustainability initiatives were interpreted as coping mechanisms and mechanisms of re-embedding. Our analysis allows conclusions to be drawn on the effectiveness of initiatives introduced by the banks interviewed in enhancing societal welfare, protecting the environment, and working towards managing climate change risks. The managerial implication of this paper could help sustainability initiatives setters and financial institutions to develop and explore more coherent incentives and motivations to rebuild their trust and reputation.

Nevertheless, it is hoped that future research will be undertaken regarding specific ways in $\underline{\text { which banks and financial institutions are able to adapt compulsory sustainability measures }}$ and/ or initiatives to create tangible enhancement for society and the environment. In addition, this kind of research may explore more organisational sustainability practices to rebuild societal trust and managing the high consequence risks of climate change and $\underline{\text { financial crisis. }}$ 


\section{References}

Aklitar, S. (2007). Sustainability and Challenges. Economic Review, 9(10), 43-47.

Aracil, E., Nájera-Sánchez, J.-J. \& Forcadell, F. J., 2021. Sustainable banking: A literature review and integrative framework. Finance Research Letters

Atkins, J. and Atkins, B. (2019). Around the World in 80 Species: Exploring the Business of Extinction, Routledge, UK.

Atkins, J. and Macpherson, M. (2019). "Developing a Species Protection Action Plan - An Integrated Approach for Taxonomies, Reporting and Engagement for the Financial Services Sector", Concept Paper circulated at Investec Bank’s Natural Capital, Species Extinction and Sustainable Financial Markets Event, 30th May.

Baumgartner, R. J., and Ebner, D. (2010). Corporate sustainability strategies: Sustainability profiles and maturity levels. Sustainable Development, 18 (2). 76-89.

Beck, T., Demirgüç-Kunt, A., and Levine, R. (2010). Financial institutions and markets across countries and over time: The updated financial development and structure database. The World Bank Economic Review, 24 (1). 77-92.

Beck, U. (1987). The Anthropological Shock: Chernobyl and the Contours of the Risk Society. Berkeley Journal of Sociology. Vol. 32(1). 153 - 165.

Beck, U. (1992). Risk Society: Towards a New Modernity, London.

Beck, U. (1997). Sub-politics: ecology and the disintegration of institutional power", Organization and Environment, 10 (1). 52-65

Beck, U. (1999). World Risk Society. Blackwell Publishers, Cambridge.

Beck, U. (2007). Beyond Class and Nation: Refraiming Social Inequalities in a Globalised World. The British Journal of Sociology. Vol 58 (4).

Beck, U. (2009). World at Risk. Polity Press. Cambridge. 
Beck, U., Giddens, A., Lash, S. (1994). Reflexive Modernization: Politics, Tradition and Aesthetics in the Modern Social Order. Stanford University Press. California.

Berglof, E. (2011). A European perspective on the global financial crisis, Corporate Governance: An International Review, 19(5). 497-501.

Bihari, S. C. (2010). Green Banking-Towards Socially Resonsible Banking in India. Journal of Business Insights and Transformation, October, 4(1). 82-88.

Boiral, O. (2006). Global warming: should companies adopt a proactive strategy? Long Range Planning 39(3). 315-330.

Bryman, A. and Bell, E. (2007). Business Research Methods. 2nd Ed. Oxford, Oxford University Press.

Bryson, D., G. Atwal, A. Chaudhuri, and K. Dave. (2016). "Antecedents of Intention to Use Green Banking Services in India.” Strategic Change (25). 551-567.

Burgess, A., Wardman, J., Mythen, G. (2017). “Considerng risk: placing the work of Ulrich Beck in context", Journal of Risk Research, editorial, November.1-5.

Contreras, G., W.B.Bos, J. \& Kleimeier, S., 2019. Self-regulation in sustainable finance: The adoption of the Equator Principles. World Development, (122). 306-324.

Conyon, M., Judge, W. Q. and Useem, M. (2011). Corporate governance and the 2008-2009 financial crisis, Guest Editorial, Corporate Governance: An International Review, 19(5). 399404.

Coulson, A. B., (2009). How Should Banks Govern the Environment? Challenging the Construction of Action Versus Veto. Business Strategy and the Environment, 18(3). 149-161. Deepa, P., and D. C. Karpagam. (2018). “A Study on Customer's Awareness on Green Banking in Selected Public and Private Sector Banks with Reference to Tirupur." International Journal of Advanced Research and Development 3 (1). 58-63. 
Delgado-Márquez, B. L., and Pedauga, L. E. (2017). Environmental behavior and MNEs: A strategy pulled by stakeholder engagement. Business Strategy and the Environment, 26(7). 927-939.

Dell'Atti, S., Trotta, A., Iannuzzi, A. P., and Demaria, F. (2017). Corporate social responsibility engagement as a determinant of bank reputation: An empirical analysis. Corporate Social Responsibility and Environmental Management, 24(6). 589-605.

Englert, M. R., Koch, C., and Wüstemann, J. (2018). The effects of financial crisis on the organizational reputation of banks: An empirical analysis of newspaper articles. Business and Society, $1-35$.

Fanasch, P. (2019). Survival of the fittest: The impact of eco-certification and reputation on firm performance. Business Strategy and the Environment, 28(4), 611-628.

Fombrun, C. J. (2005). A world of reputation research, analysis and thinking-building corporate reputation through CSR initiatives: Evolving standards. Corporate Reputation Review, 8(1). 7-12.

Forcadell FJ, Aracil E, Ubeda F.(2020). "Using reputation for corporate sustainability to tackle banks digitalization challenges”, Business Strategy and the Environment, 1-13.

Forcadell, F. J., and Aracil, E. (2017). European banks' reputation for corporate social responsibility. Corporate Social Responsibility and Environmental Management, 24(1). 1-14. Gallego-Alvarez, I., and Pucheta-Martínez, M. C. (2019). Environmental strategy in the global banking industry within the varieties of capitalism approach: The moderating role of gender diversity and board members with specific skills. Business Strategy and the Environment, 347-360.

Giddens, A. (1987). Social Theory and Modern Sociology. Stanford University Press. California. 
Giddens, A. (1990). The Consequences of Modernity. Stanford University Press. Stanford California.

Giddens, A. (1991). Modern and Self-Identity: Self and Society in the Late Modern Age. Blackwell Publishing. Cambridge.

Giddens, A. (1992). The Transformation of Intimacy: Sexuality, Love, and Eroticism in Modern Societies. Stanford University Press.

Giddens, A. (1994). Living in a Post-Traditional Society. In Beck, U., Giddens, A., and Lash, S. (eds), Reflexive Modernisation: Politics, Tradition and Aesthetics in the Modern Social Order. 56 - 109. Polity. Cambridge England.

Giddens, A. (1998). Risk Society: The Context of British Politics. In Franklin, J. (eds). The Politics of Risk Society Order. Polity Press. Cambridge.

Giddens, A. (1999). Risk and Responsibilities. The Modern Law Review. Vol. 62(1). 1 - 10.

Giddens, A. and Pierson, C. (1998), Conversations with Anthony Giddens: Making Sense of Modernity, Blackwell, Oxford.

Giddens, A. (2009). Sociology (Sixth Edition). Cambridge, Policy Network: Polity. Giddens, A. (2011). The Politics of Climate Change, Polity Press, Cambridge, UK.

Gray, R. and Bebbington, J. (2001). Accounting for the Environment. 2nd Ed. London: SAGE Publications Ltd.

Gray, R. and Milne, M. (2002). Sustainability Reporting: Who's Kidding Whom. Chartered Accountants Journal of New Zealand, 81(6). 66-70.

Hubbard, G. (2009). Measuring organizational performance: Beyond the triple bottom line. Business Strategy and the Environment, 18(3), 177-191. https://doi.org/10.1002/bse.564 Jabbour, LS, Jabbour, CJC. (2009). Are supplier selection criteria going green? Case studies of companies in Brazil. Industrial Management and Data Systems 109(4). 477-495. 
Jeucken, M. (2004), Sustainability in Finance- Banking on the Planet. Netherland: Eburon Academic Publishers.

Jeucken, M. (2010). Sustainable finance and banking: The financial sector and the future of the planet. Routledge.

Kapoor, N., Jaitly, M., and Gupta, R. (2016). “Green Banking: A Step Towards Sustainable Development." International Journal of Research in Management, Economics, and Commerce 6 (7). 69-72.

Kay, J. (2012). The Kay Review of UK Equity Markets and Long-Term Decision Making, Final Report, July.

Kim, G., Shin, B., and Lee, H. G. (2009). Understanding dynamics between initial trust and usage intentions of mobile banking. Information Systems Journal, 19(3). 283-311.

Kyriakos, C. et al., 2021. A new practical methodology for the banking sector to assess $\underline{\text { corporate sustainability risks with an application in the energy sector. Sustainable Production }}$ and Consumption.

Lai, A., Melloni, G., and Stacchezzini, R. (2016). Corporate sustainable development: Is 'integrated reporting' a legitimation strategy? Business Strategy and the Environment, 25(3). $165-177$.

Lindenberg, N., and Volz, P. (2016). Green Banking Regulation-Setting out a Framework. UN City of Bonn: German Development Institute.

Macve, R. and Chen, X. (2010). The "Equator Principles": A Success for Voluntary Codes?. Accounting, Auditing and Accountability Journal, 23(7). 890-919.

Masukujjama, M., Siwa, C., Mahmu, M., and Alam, S. (2016). "Bankers' Perception of Green Banking: Learning From the Experience of Islamic Banks in Bangladesh.” Malaysian Journal of Society and Space, 12(2). 
Mehedi,S., Kuddus, M., and Maniruzzaman, M. (2017). "The Identification of Bankers' Perception Toward Indicators For The Adoption Of Green Banking In Bangladeshi Scheduled Commercial Banks.” Journal of Internet Banking and Commerce 22 (2). 1-18.

McElroy, M. and Engelen, J. V. (2012). Corporate Sustainability Management, 1st Ed. New York: Earthscan.

Miles, M. B., Huberman, M. and Saldaña, J. (2014). Qualitative Data Analysis; A Methods Sourcebook. 3rd Ed., SAGE Publications Inc .

Milne, M. J. and Gray, R. (2013). W(h)ither Ecology? The Triple Bottom Line, the Global Reporting Initiative, and Corporate Sustainability Reporting. Journal of Business Ethics, 118(1), 13-29.

Miras-Rodríguez, M., Carrasco-Gallego, A., and Escobar-Pérez, B. (2015). Has the CSR engagement of electrical companies had an effect on their performance? A closer look at the environment. Business Strategy and the Environment, 24(8). 819-835.

Moxey, P. and Berendt, A. (2008). Corporate governance and the credit crunch, ACCA Discussion Paper, November, ACCA, London.

Nienaber, A. Hofeditz, M., and Searle, H. (2014). Do we bank on regulation or reputation? A meta-analysis and meta-regression of organizational trust in the financial services sector. International Journal of Bank Marketing, 32(5). 367-407.

Orlitzky, M., Schmidt, F. L., and Rynes, S. L. (2003). Corporate social and financial performance: A meta-analysis. Organization Studies, 24(3). 403-441.

Ortiz-de-Mandojana N, and Bansal, P. (2015). The long-term benefits of organizational resilience through sustainable business practices. Strategic Management Journal 37(8). 16151631. 
Park, S. B. (2018). Multinationals and sustainable development: Does internationalization develop corporate sustainability of emerging market multinationals? Business Strategy and the Environment, 27(8). 1514-1524.

Pérez, A., and del Bosque, I. R. (2015). How customer support for corporate social responsibility influences the image of companies: Evidence from the banking industry. Corporate Social Responsibility and Environmental Management, 22(3). 155-168.

Prakash Pillai, R., and Praveen Raj, D. (2019). "Perspective and Usage Patterns of Green Banking Services: A Cross-Sectional Analysis of Customers From Selected Banks in Kerala.” Research Review International Journal of Multidisciplinary 4 (2). 285-292.

Prerana, S. and Arup, R. (2020). “A Scientometric analysis of literature on Green Banking”, Journal of Sustainable Finance and Investment

Raut, R., Cheikhrouhou, N., and Kharat, M. (2017). "Sustainability in the banking industry: A strategic multi-criterion analysis", Business Strategy and the Environment, Volume 26, Issue 4.

Relaño, F. (2011) "Maximizing social return in the banking sector”, Corporate Governance: The International Journal of Business in Society, 11(3).

Ruiz, B., Esteban, A., and Gutierrez, S. (2014). Determinants of reputation of leading Spanish financial institutions among their customers in a context of economic crisis. BRQ Business Research Quarterly, 17(4). 259-278.

San-Jose, L., Retolaza, J. L. and Gutierrez-Goiria, J. (2011). Are Ethical Banks Different? A Comparative Analysis Using the Radical Affinity Index. Journal of Business Ethics, (100). 151-173.

Sarma, P. and Roy, A. (2020). A Scientometric analysis of literature on Green Banking (1995-March 2019), Journal of Sustainable Finance and Investment, DOI: $10.1080 / 20430795.2020 .1711500$ 
Scholtens, B. (2009). Corporate social responsibility in the international banking industry. Journal of Business Ethics, 86(2). 159-175.

Scholtens, B. (2017). Why finance should care about ecology. Trends in Ecology and Evolution, 32(7). 500-505.

Scholtens, B. and Dam, L. (2007) "Banking on the Equator: Are banks that adopted the Equator Principles different from non-adopters?”, World Development, (35).1307-1328.

Shen L, Olfat L, Govindan, K., Khodaverdi, R., and Diabat, A. (2012). A fuzzy multi criteria approach forevaluating green supplier's performance in green supply chain with linguistic preferences. Resources, Conservation and Recycling 74(1). 170-179.

Solomon, J. F., Solomon, A. Joseph N. L. and Norton, S. D. (2011). "Private Climate Change Reporting: A Discourse of Risk and Opportunity?", Accounting, Auditing and Accountability Journal, 24(8).1119-1148.

Solomon, J. (2020, forthcoming). Corporate Governance and Accountability, John Wiley and Sons Inc., 5th edition, Chichester, UK.

The Equator Principles (2014). The Equator Principles Implementation Note, It could be accessed via https://equator-principles.com/ep-association-news/implementation-note/ (Accessed on $16^{\text {th }}$ June 2020)

Torelli, R., Balluchi, F., and Lazzini, A. (2019). Greenwashing and environmental communication: Effects on stakeholders' perceptions. Business Strategy and the Environment, 407-421.

UNEP FI, (2011). United Nations Environmental Programme Finance Initiative. [Online] Available at: https://www.unepfi.org/[Accessed 14th October 2019].

Walker, D. (2009). A Review of Corporate Governance in UK Banks and other Financial Industry Entities, The Association of Chartered Certified Accountants (ACCA), The Walker Review Secretariat, London 26 NovemberOctober . 
Yip, A. W., and Bocken, N. M. (2018). Sustainable business model archetypes for the banking industry. Journal of Cleaner Production, 174, 150-169. 


\section{First: Introduction}

Societal trust in banks has collapsed as a result of excessive risk taking, poor structures for executive remuneration, inadequate risk management, unethical behaviour and poor social responsibility during the global financial crisis (Conyon et al., 2011; Kay Review, 2012; Ruiz et al., 2014; Solomon 2020; Walker Review, 2009). One only has to consider the bailout of banks considered 'too big to fail' (Conyon et al., 2011) to appreciate why society's faith and trust in banks has been rocked (Solomon, 2020). Berglof (2011) concluded that the financial crisis would refocus banks' attention on risk and risk management. Indeed, the destruction of banks' reputations following the global financial crisis has been well-documented in the academic literature (Dell'Atti et al., 2017; Englert et al., 2018; Forcadell and Aracil, 2017).

In addition to the collapse in trust and reputation arising from the financial crisis, banks are also witnessing the alienating effects of dis-embedding ${ }^{1}$ mechanisms, such as increased online banking, the closure of physical banks in towns and cities, the rise of call centres at the other side of the world from clients/customers, all of which represent abstract systems ${ }^{2}$ that create time-space distanciation. Such systems rely on societal trust at a time when trust in banks and in financial institutions generally is at an all-time low. The process of replacing face to face financial systems with 'faceless' commitments (Giddens, 1990; 1991) makes it harder for society to trust banks and other institutions. This need for trust in today's financial banking systems, combined with the collapse of societal trust arising from the financial crisis, has created an urgent need for banks to rebuild trust among their stakeholders and reinstate

\footnotetext{
1 Dis-embedding is defined as the 'lifting out' of social relationships from local contexts and their recombination across indefinite time/space distances (Giddens, 1991).

2 In Giddensian sociological language, abstract systems refer to symbolic tokens and expert systems, where symbolic tokens are defined as media of exchange that have standard value and are thus interchangeable across an indefinite variety of contexts (such as money or funds), and expert systems are defined as systems of expert knowledge, of any type, depending on rules of procedure transferable from individual to individual (Giddens, 1991). Expert systems can be interpreted as banking and financial systems.
} 
their reputations. The Kay Review raised this and provided a way forward for banks and other financial institutions (Kay Review, 2012).

As well as addressing reputational damage from the global financial crisis, banks face increasing challenges associated with climate change and related risks, and green/sustainable banking strategies can assist banks in restoring reputation (Dell'Atti et al., 2017; Englert et al., 2018; Forcadell and Aracil, 2017; Gallego-Alvarez and Pucheta-Martinez, 2019; Pérez and del Bosque, 2015). A sustainable approach to business represents an effective means of enhancing reputation as sustainability initiatives can assist in rebuilding stakeholder confidence (Fombrun, 2005; Forcadell et al., 2020). From a sociological perspective, sustainability initiatives, we suggest, represent re-embedding ${ }^{3}$ mechanisms, that can enhance societal trust in banking systems. Further, enhanced reputation can lead to higher levels of trust as it signals greater credibility (Nienaber et al., 2014).

Developing and implementing sustainability initiatives and practices is one way that organisations can enhance their reputation (Miras-Rodriguez et al., 2015; Delgado-Marquez and Padauga, 2017; Fanasch, 2019; Kim et al., 2009; Lai et al., 2016; Orlitzsky et al., 2003; Park, 2018; Torelli et al., 2019).

This paper seeks to fill the research gap by exploring the application of sustainability practices in relation to banks' implementation of sustainability initiatives such as the Equator Principles, through extensive interviews with representatives from leading banks based in the $\underline{\text { UK. Further, we interpret the empirical data through a theoretical framework around risk and }}$ risk management, deriving from sociology, especially the works of Giddens and Beck.

\footnotetext{
${ }^{3}$ The online Oxford Reference defines re-embedding as, "New forms of social relations, communities, and politics (see globalization) arising alongside a decline in traditional forms of social cohesion", https://www.oxfordreference.com/view/10.1093/oi/authority.20110803100410665
} 
This paper seeks to explore the application of sustainability in relation to banks' implementation of sustainability initiatives such as the Equator Principles, through extensive interviews with representatives from leading banks based in the UK. Further, we interpret the interview data through a theoretical framework around risk and risk management, deriving from sociology, especially the works of Giddens and Beck. We interpret the interview findings through a lens of sociological theory that reveals sustainability initiatives to be imbued with reputational risk management but also indicates that some sustainability initiatives were interpreted as coping mechanisms and mechanisms of re-embedding. Our analysis allows conclusions to be drawn on the effectiveness of initiatives introduced by the banks interviewed in enhancing societal welfare, protecting the environment, and working towards reducing climate change.

\section{Second: Literature review:}

The literature review surveys prior studies in the following four main themes. Theme One provides a review of sustainable banking, green banking and the Equator Principles. Theme Two theorising banking sustainability initiatives through sociological and financial frameworks. Theme Three reviews ecological risks: dis-embedding, re-embedding, coping mechanisms and ontological security. Theme four analyses trust and risk: sustainability initiatives as a mean of restoring societal trust.

\section{Second2.1 Theme one: A review of sustainable banking, green banking and the Equator Principles}

As the world continues to witness unprecedented anthropogenic climate change and its impact on societies and biodiversity, attention is turning increasingly to the finance industry to encourage banks, institutional investors, businesses and the accounting firms to incorporate 
social environmental and sustainability concerns into their decision-making and strategies (Solomon, 2020; Scholtens, 2017; Atkins and Macpherson, 2019; Atkins and Atkins, 2019). Such high consequence risks are an intrinsic part of $21^{\text {st }}$ century societies, being “...risks deriving from the globalised character of the social systems of modernity”, as, "...nature, ...has in a certain sense come to an 'end' - as a result of domination by human beings - the risks of ecological catastrophe form an inevitable part of our horizon of day-to-day life" (Giddens, 1991, p.4). Indeed, Giddens considers climate change to constitute a fundamental threat to the future of global industrial civilisation (Giddens, 2009).

Globally, organizations are seeking to balance environmental, social and economic performance through sustainable development (SD hereafter) practices (Boiral, 2006; Jabbour and Jabbour, 2009; Hubbard, 2009; Baumgartner and Ebner, 2010; Shen et al., 2012; Ortizde-Mandojana and Bansal, 2015; Raut et al., 2017; Ozbekler and Ozturkoglu, 2020). Indeed, the social and environmental impacts of banks and other financial institutions have been recognised for some time as significant factors contributing to effective corporate governance (Coulson, 2009). The indirect impacts of banking on the environment are substantial and therefore they have an important role to play in SD through implementing sustainability initiatives (Beck et al., 2010; Yip and Bocken, 2018; Forcadell et al., 2020).

In the area of banking and sustainability, there is a growing literature focusing on 'sustainable banking' (Aracil, 2021), to vivid societal debate around the role of banks in the advancement toward sustainability. It involves which includes research into environmental protection through banks' investment in goods and services (Lindenberg and Volz, 2016). Indeed, there are two areas of sustainable and green banking that have attracted research interest: firstly, banks' internal initiatives, such as reducing paper usage and waste, and secondly, external 
initiatives, involving how the banks choose to invest funds (Sarma and Roy 2019). Some of the prior literature has focused on the advantages and disadvantages of green banking (Kapoor, Jaitly, and Gupta 2016). Various studies have considered the attitudes of bankers (Masukujjama et al. 2016; Mehedi, Kuddus, and Maniruzzaman 2017). Other research has concentrated on banking clients (Bryson et al. 2016; Prakash Pillai and Praveen Raj 2019; Deepa and Karpagam 2018), while some have studied penetration among the bankers.

'Green Banking' has evolved that seeks to limit banks' climate change impacts, at the same time investing in environmental goods and services (Lindenberg and Volz, 2016). One only has to consider recent media coverage of pressures from activist environmental Nonegovernmental Organisations (NGOs hereafter) on banks and financial institutions to appreciate the growing societal voice, for example the recent forced closures of Barclays branches in response to Greenpeace action. ${ }^{4}$ In recent years, banks have been responding to calls for greater accountability in relation to sustainability, and especially environmental issues, in primarily two ways: internally, by introducing social and environmental initiatives such as recycling and waste reduction, and; externally, by developing and applying social and environmental criteria to their lending decisions (Sarma and Roy, 2019). This second category of initiatives represents in part a response to the establishment of global principles and guidelines such as the Equator Principles. The role of the banking sector in allocating funds affords banks the potential to influence companies and organisations generally to become more sustainable and to pay greater attention to social and environmental considerations (Jeucken, 2010).

The introduction of the Sustainable Development Goals (SDGs hereafter) by the United Nations (UN hereafter) is driving governments and organisations across all sectors to adopt proactive measures and initiatives to address the challenges posed by the 17 SDGs. Such

${ }^{4}$ See article on the BBC website entitled, "Climate Change: Greenpeace Stops Barclays from Opening Branches" at https://www.bbc.co.uk/news/business-51702865 Accessed on $2^{\text {nd }}$ March 2020 
pressures were originally designed on a voluntary basis to manage these considerations in more effective and transparent sustainability principles (Macve and Chen, 2010). They aim to explore how business-organisations could use accounting tools and practices to apply sustainability principles to manage the main imperatives of SD. These imperatives involve a set of different dimensions to ensure fair and equal allocation of resources and opportunities between current and future generations/stakeholders (Gray and Milne, 2002). The effective management of these dimensions requires sensible considerations of some business imperatives e.g. fairness, accountability and ethical responsibilities (Grubnic, et al., 2015). Moreover, these imperatives involve incorporating climate change; ecological biodiversity, earbon emissions; human rights issues; global water shortage problems, and income and gender equality into core business activities. The determination of the needs of future stakeholders (generations) involve some measurement challenges and difficulties to predict these future needs and expectations (McElroy and Engelen, 2012). These developments are occurring across all sectors including the financial industry, with initiatives such as the Equator Principles being implemented by banks and other financial institutions. Despite these developments, the banking sector has been relatively under-researched in the area of SD, in eomparison to other sectors (Rant et al., 2017). We seek to address this relatively under researched research gap.

The Equator Principles are one of the most significant external sustainability initiatives that banks around the world can engage_(Contreras, 2019). They represent a risk management framework, adopted by financial institutions, for determining, assessing and managing environmental and social risk in project finance (Equator Principles, 2014). They are perceived as a risk management approach (Abb et al., 2017). The Equator Principles are primarily intended to provide a minimum standard for due diligence to support responsible risk decision-making. The Principles apply globally, to all industry sectors and to four 
financial products: project finance, advisory services, project related corporate loans and bridge loans. The Equator Principles Association is the unincorporated association representing the member Equator Principles Financial Institutions (EPFIs hereafter) and Associates whose objective is the management, administration and development of the Equator Principles (Equator Principles, 2014). This umbrella Association was formed on 1 July 2010 with the aim of ensuring long-term viability and ease of management of the member EPFIs and Associates (ibid). An EPFI is a financial institution which has adopted the Equator Principles in accordance with the procedures in these rules, is active in project finance and whose name appears as an EPFI on the list of EPFIs and Equator Principles working groups. Each EPFI shall introduce and implement its own internal social and environmental risk management policies, procedures and standards in order to comply with the Equator Principles. All EPFIs have to apply all the principles to all new projects over $\$ 10 \mathrm{~m}$ from the date of adoption. The objectives of the Equator Principles are to: Promote and encourage the adoption of the Principles by more financial institutions; Promote and encourage the implementation of the Principles by the EPFIs and Associates in a manner consistent with good international banking practice and all applicable law and that offers reasonable consistency of approach; Develop the Principles as the EPFIs and Associates consider appropriate, having regard to developments in international practice, the evolution of sustainability standards, and the practices and the views of stakeholders; Maintain contact and share expertise with international financial institutions and other bodies who have developed their own social and environmental standards (Equator Principles, 2014).

The adoption of the Equator Principles is open to any financial institution that meets the relevant adoption requirements and agrees to meet the on going reporting requirements. Adoption by a financial institution is voluntary but once such adoption has been made, the 
adopting entity must take all appropriate steps to implement and comply with the Equator Principles (Equator Principles, 2014).

\section{Third 2.2 Theme Two: Theorising banking sustainability initiatives through sociological and financial frameworks}

The Equator Principles have become the financial industry standard for environmental and social risk management in project finance in some countries (Scholtens and Dam, 2007). Financial institutions adopt the Equator-Principles to ensure that the projects they finance are developed in a socially responsible manner and reflect sound environmental management practices. By doing so, negative impacts on project-affected ecosystems and communities should be avoided where possible, and if unavoidable, should be reduced, mitigated and/or compensated for appropriately. Adopters believe that the adoption of, and adherence to, the Principles offer significant benefits for themselves, and for their borrowers and local stakeholders through their borrowers' engagement with locally affected communities (Ibid). Adopters should be able to better assess, mitigate, document and monitor the credit and reputation risk associated with financing development projects. Additionally, the collaboration and learning on broader policy application, interpretation and methodologies between adopters, and with their stakeholders, helps knowledge transfer, learning and best practice development (Macve and Chen, 2010). The adopters' role as financiers affords them opportunities to promote responsible environmental stewardship and socially responsible development.developing sustainable criteria into their lending processes in order to reduce corporate sustainability risk (Kyriakos, 2021).

The relevant thresholds and criteria for their application is described in detail in the Scope section of the Equator Principles EPFIs commit to implementing the Principles in their internal environmental and social policies, procedures and standards for financing projects and will not provide project finance or project related corporate loans to projects where the 
elient will not, or is unable to, comply with the Principles. While they are not intended to be applied retroactively, EPFIs apply them to the expansion or upgrade of an existing project where changes in scale or scope create significant environmental and social risks and impacts, or significantly change the nature or degree of an existing impact.

Recent research shows that 94 EPFIs in 37 countries have officially adopted the Equator Principles, covering many international project finance debt in emerging markets (Equator Principles, 2014). The Principles have increased the attention and focus on social/community standards and responsibility, including robust standards for indigenous peoples, labour standards, and consultation with locally affected communities within the project finance market. They have also promoted convergence around common environmental and social standards. Multilateral development banks, including the European Bank for Reconstruction and Development, and some credit agencies through the Organisation for Economic $\mathrm{Co}$ operation and Development (OECD) are increasingly drawing on social and environmental standards as the Principles.

Another series of external sustainability initiatives include the shared effort to promote responsible environmental and social management practices in the financial sector and banking industry from The United Nations Environmental Programme Finance Initiative (UNEP FI hereafter). These initiatives have provided a platform for engagement with a broad range of interested stakeholders, including non-governmental organisations (NGOs), clients and industry bodies (UNEP FI, 2018).

Sociologists have sought to understand and theorise shifts in societal attitude associated with the emergence and increasing awareness of global threats to people and the planet for several decades. Ulrich Beck and Anthony Giddens, German and British sociologists respectively, have been significant in contributing to this understanding. Beck's (1992) risk society thesis built upon the characteristics of modernity (Giddens, 1990; 1991), identifying risk as a 
primary factor shaping society, institutions, politics and individual life choices. Beck defined risk society as, "a systematic way of dealing with hazards and insecurities induced and introduced by modernisation itself (Beck 1992:21)". Further, Giddens defined risk society as, "...a society increasingly preoccupied with the future (and also with safety), which generates the notion of risk," (Giddens and Pierson 1998, p.209). Altering financial systems and institutions such as banking is essential if the world is to adapt to impending climate change risks and alter the path, as, “... there has to be a profound restructuring of financial markets themselves and of banking" (Giddens, 2011, p.150).

\section{Fourth 2.3 Theme Three: Ecological risks: dis-embedding, re-embedding, coping mechanisms and ontological security}

One focus of Giddens' and Beck's work has been the ecological dimension of the risk society, as they perceived that humans' impact on the natural environment was affecting society at a deep level through the catastrophic risks faced by environmental degradation. Beck (1997) suggested that the way in which institutions were organised was not appropriate for the effective management of risk in a risk society. In the face of severe ecological problems, companies fall into either, "... the role of villain and poisoner, or ... the role of the hero and helper and celebrate this publicly.... "(Beck, 1997, p.61).

Giddens, in The Politics of Climate Change (Giddens, 2011) explored the unprecedented challenges faced by humans and capitalism arising from anthropogenic global warming and related effects. Beck (1997) described two constellations in the ecological conflict. One is characterised by confrontation, where polluter industries and affected groups confront each other. He explained that this constellation only begins to change when a second emerges where external interested parties get involved and the collaboration between polluters and 
victims which covers up the 'truth' starts to disintegrate. This happens as the industry recognises it is part of a risk society. Accountability for the emergence of high consequence risks and their impact is difficult to pinpoint due to chains of inter-related responsibility. It is almost impossible in our society, which is characterised by complicated webs of inter-linked accountability, to attribute blame or responsibility to anyone source. Scientific proof of linkage between cause and effect relating to risk analysis is being used as a means of dismissing risks. Beck also suggested that by insisting on scientific proof of causality, companies were able to escape accountability.

"By turning up the standard of scientific accuracy, the circle of recognised risks justifying action is minimized, and consequently, the scientific license is implicitly granted for the multiplication of risks. To put it bluntly: insisting on the purity of the scientific analysis leads to the pollution and contamination of air, foodstuffs, water, soil, plants, animals and people. What results then is a covert coalition between strict scientific practice and the threats to life encouraged or tolerated by it" (Beck, 1992, p.62).

The sustainability-related risks associated with business activity have many characteristics described by Beck (1992) and Giddens (1991). Firstly, the risks in contemporary society differ from risks in previous eras as they are invisible and difficult to detect. For example, radiation or pollutants in farmed produce are not detectible to the nose or eye, only their effects are felt. Another characteristic of risks in the situation of late modernity is that their consequences will be devastating for communities, the environment or biodiversity. They are, in Giddens' (1991) terms, 'high consequence' risks. The emergence of high consequence risks, especially social, environmental and sustainability risks has been highlighted as a societal trend (Giddens, 1991; Beck, 1992). This proliferation of high consequence risks has posed 
problems for society and especially for companies, who have been held increasingly accountable for their creation. ${ }^{5}$ Beck (1997) focused specifically on ecologically-derived risks and their effects on society, institutions and politics. The awareness of high consequence risks which represent dangers from which no one can be completely free has now become part of individuals' 'umwelt', the cocoon of relevance and normalcy with which individuals surround themselves in order to place themselves in the world (Goffman, 1971). Giddens (1991) defined an individual's protective cocoon as the mantle of trust that makes possible the sustaining of a viable Umwelt. This trust incorporates an attempt by individuals to come to terms with high consequence risk, either by accepting them, actively trying to reduce them (by recycling, for example) or by giving up worrying about them. The threat of climate change and the potentially apocalyptic implications arising from human impacts on the planet, nature and the environment are threatening to people's ontological security, making them feel insecure in the face of high consequence risks.

Beck (1999) explains that risk in the era of the 'risk society' involves approaches aimed at foreseeing and controlling the future unintended consequences arising from human actions and states that the risks from modernisation are irreversible threats to people, flora and fauna (Beck, 1992). The grow th of the media has also contributed greatly to the increase in awareness of risks, especially in the sustainability area. Giddens (1991) discussed the way in which the development of electronic media has contributed to the construction of a reflexive modernity.

A further characteristic of the risk society thesis is that people are so overwhelmed by risk information that there is a tendency for them to stop caring (Beck, 1992). There is a general

\footnotetext{
${ }^{5}$ The emergence of high consequence risks represents the dark side of modernity, being created by the rapidity of social and technological change. The types of risk falling into this category arise from the 'human control of natural and social worlds' (Giddens, 1991, p.109). Specifically, Giddens (1990) sketched an array of high consequence risks including the growth of totalitarian power, the collapse of economic growth, nuclear conflict or large-scale warfare, and ecological decay or disaster. Clearly, sustainability risks arising from corporate activity represent a significant ingredient in the materialisation of these high consequence risks.
} 
state of apathy among members of society arising from a feeling of helplessness. People switch off to risks because it is not 'normal' to worry constantly about high consequence risks such as nuclear war, as this would detract from coping with the practical aspects of everyday life. There is a numbing effect on society of constantly listing dangers, which ereates apathy (Giddens, 1990). This also transtates into feelings of 'engulfment' (Giddens, 1990 , p.193) where people feel so overwhelmed by the potential risks and consequences arising from global warming and climate change that they cannot cope and react by trying not to contemplate these consequences: another response is to develop coping mechanisms that ean help to restore their ontological security. Another aspect of the risk society is that all 7 social classes are affected by risks. Whereas previously there was a division whereby higher classes could avoid risks, they cannot avoid the high consequence risks now pervading the economy.

We suggest that from a risk society theoretical perspective, banks' sustainability initiatives represent forms of coping mechanism, by which bank employees can feel they are addressing sustainability and related ecological risks through implementing initiatives. Such initiatives were interpreted as a means of re-embedding, rebuilding relationships between banks, their clients and other stakeholders. Perceiving sustainability initiatives in this way also leads us to consider the trust dimensions of the risk society theoretical framework and how this will be interpreted in relation to banks' sustainability initiatives.

\section{Fifth 2.4 Theme Four: Trust and Risk: Sustainability initiatives as a means of restoring societal trust}

One of the salient characteristics of the risk society has been identified as a loss of trust. However, the interpretation of the role of trust in a risk society differs from the work of Beck and Giddens. Whereas Beck considered that the monumental rise in societal risk in recent 
years has created a less trusting, confident society, characterised by societal anxiety, Giddens' view is somewhat different. Giddens (1990) considered that there is not necessarily a higher level of risk, but that society has become more reflexive. This increase in reflexivity has led to a decline in trust, which in turn has led society to be more anxious and more preoccupied with risks and their potential consequences. Again, reflexivity has been flagged up as a cornerstone of the risk society thesis, but there are various interpretations of the term and its implications (see, for example, Giddens, 1990, p.36).

From a Giddensian viewpoint, institutions face a crisis of trust, given the current trend in society to lose trust in institutions and organisations (Giddens, 1992). Further, sociologists have claimed that society is turning to counter-experts to replace the loss of confidence in traditional experts (Beck, 1992). Giddens (1990) explored the relationship between trust and risk. He examined the relationship between confidence and trust, suggesting that a distinction between the two has been made whereby trust should be understood specifically in relation to risk. He explains that,

"risk largely replaces what was previously thought of as Fortmna (fortune or fate) and becomes separated from cosmologies. Trust presupposes an awareness of circumstances of risk, whereas confidence does not. Trust and confidence both refer to expectations that can be frustrated or cast down (Giddens, 1990, pp30-31).

He then goes on to set down his theory of risk and trust as follows. Trust is linked with eontingency rather than with risk. Trust always carries the connotation of reliability in the face of contingent outcomes. Giddens stated that risk and trust intertwine and that trust generally serves to reduce or minimise the dangers to which particular types of activity are subject. In other words, building and establishing trust represents, in the Giddensian risk society framework, a form of risk management. Restoring trust and building confidence is a way of managing risk and therefore reducing societal anxiety, countering a loss of ontological 
security. There are some circumstances in which patterns of risk could be institutionalised, within surrounding frameworks of trust (stock market investments, for example).

Preserving corporate image, managing impressions and maintaining a 'good' external reputation among stakeholders is an integral part of Beck's risk society, as he explains,

"Those who find themselves in the public pillory as risk producers refute the charges as well as they can, with the aid of a 'counter-science' gradually becoming institutionalised in industry, and attempt to bring in other causes and thus other originators. The picture reproduces itself. Access to the media becomes crucial. The insecurity within industry intensifies: no one knows who will be struck next by the anathema of ecological morality. Good arguments, or at least arguments capable of convincing the public, become a condition of business success. Publicity people, the argumentation craftsmen, get their opportunity in the organisation (Beck, 1992, p.32).

Although banks, like other organisations, are aware of the need to implement sustainability initiatives and introduce SD strategies and policies, the risks attached to the concept of sustainability was less clear. Banks implement sustainability initiatives in a state of nichtwissen (not knowing), a concept discussed in Beck's risk society thesis. What risks are these initiatives being introduced to manage? Climate change? Social inequalities? Are these social and environmental risks manageable? How are they manifesting themselves? Why and how are these initiatives going to 'manage' these risks? If there is little or no understanding of the risks being addressed by such initiatives, then why are they being introduced at all? The interviews discussed in this paper provide some appreciation of the motivations underlying their introduction.

We consider that sustainability initiatives represent re-embedding and risk management mechanisms, especially the large-scale external initiatives such as the Equator Principles as they are a means of rebuilding societal trust in the banking sector, at the same time seeking to 
manage the risks arising from climate change, including reputational risk. Further, we suggest that some sustainability initiatives represent coping mechanisms, providing bank employees with an impression that they are controlling or mitigating the overwhelming risks associated with climate change and restoring their ontological security, giving them an illusion of control in the face of global catastrophic climate risk.

\section{SixthThird: Research method}

For this study we conducted 25 semi-structured interviews with senior representatives of 16 small and medium-sized banks operating in the UK. The interviewees' details are presented in Table 1. The interview invitations were sent out to all the targeted interviewees via email and social media. Most of the targeted interviewees were accessed through the customer services department and call centres. Through the data analysis process, some direct quotes from the interview transcripts and collected documents have been used to refer to some issues that entail significant topics to present or argue. The level of significance was determined based on the interviewees' responses and perceptions toward the main research topics and questions. The interviewees' quotes were coded in random alphabetical characters in order to ensure the interviewees' anonymity and confidentiality as indicated in the interview consent forms that have been signed by all interviewees. In order to study sustainable finance, banks seemed the appropriate focus for the study as they represent one of the most significant groups of financial intermediaries in the economy to manage SD and support the transition plans for a green economy. We interviewed both mainstream banks and banks with social/environmental and/or charitable objectives.

Risk mitigation is one of the four functions of a bank, according to Jeucken (2004). Risk mitigation by banks can achieve a positive impact on society. Banks have an extensive and comparative advantage in the information held (as a result of the knowledge they have of 
economic sectors, regulations and market developments). Furthermore, banks transform the economic resources in terms of duration, value, spatial location, and risk (see Bihari, 2010; Jeucken, 2004 and (San-Jose, et al., 2011). So, they have an embedded influence on economic growth and the welfare of societies. Therefore, it can be argued that they have a social responsibility for their investment and financing decisions to support SD. Further, the UK banking sector includes some international banks involved in SD from an Islamic perspective (e.g. Al Rayan Bank and Qatar Islamic Bank- UK QIB). Confidence in the Islamic finance system emerges from what has been claimed to be the better understanding of sustainability supported by a complete and deep social ideology to operate more ethically and responsibly within society (Aklitar, 2007). Interestingly, the UK government established the world's first investment bank solely dedicated to greening the economy in 2011. The primary purpose of this initiative is to set the UK firmly on course towards a green and growing economy, and also delivering long-term sustainable growth. Therefore, the banking industry has drawn global attention in the last few years as one of the influential sectors in the economy in the field of SD (Bihari, 2010). These banks are suppliers of debt capital as well as being institutional investors in their own preferences, so the researchers want to explore the application of sustainability principles. Also, the banking sector could be seen as one of the main sectors that could be able to manage SD. The banking sector can accumulate detailed business experience of many economic sectors and markets. This accumulated experience is gained from their own lending, investment and operational activities. Furthermore, the United Nations established, in 1992, the UNFI EP Initiative (UNEP FI, $2011)^{6}$. This Initiative represents an international partnership between the United Nations

\footnotetext{
${ }^{6}$ The three main sectors of finance, banking, insurance and investment, are represented and brought together in this global partnership. In addition, UNEP FI develops selective collaborations, UN-driven and finance sectordriven, with other partner organizations, in order to increase awareness and raise support for critical SD activities. UNEP FI contributes the perspectives of financial institutions to the various United Nations and global activities on sustainable finance. UNEP FI's activities are embedded throughout many disciplines
} 
Environment Programme and the global financial sector. The main purpose of this initiative is to develop and manage linkages between sustainability and financial performance. Accordingly, it seems particularly relevant to explore how sustainability practices could be applied in the UK banking sector.

Thematic analysis was used to analyse the interviewees' practices as more than mere factors responding to the world (Miles, et al., 2014). This approach enables researchers to explore different realities around social or human activities, and permits them to understand the behavioural contexts in which interviewees are involved (ibid). Therefore, the power of the qualitative research method focuses on exploring the meaning of words rather than quantification in the collection and analysis of data (Bryman and Bell, 2007). These deliberations have been carefully considered in developing the semi-structured interview questions in order to achieve the main research objectives. The average length of interviews was 50 minutes. All interviews were recorded and transcribed. The transcriptions were analysed interpretively, drawing themes from the data and coding interviewees' utterances through reading and re-reading.

\section{Table 1}

Interviewees' details and coding

\section{SeventhFourth: Empirical research findings}

This section presents the findings from the interview analysis according to three overriding themes, namely: (i) the interviewees' attitudes towards the Equator Principles and other

specifically the work areas of Climate Change, Ecosystems Management, Energy Efficiency and Social Issues such as creating capacity building and the sharing of best practices; setting global standards and principles and engaging stakeholders, both public and private. For more information see http://www.unepfi.org/ (Accessed on 4th January 2017) 
external sustainability initiatives; (ii) sustainability initiatives as risk management and reembedding mechanisms, and; (iii) sustainability initiatives as coping mechanisms.

\subsection{Interviewee's attitudes towards the application of sustainability principles Most of}

the interviewees were generally aware of the Equator Principles and one provided us with an in-depth description of how they were implemented in practice by their bank,

"The Equator Principles are a voluntary set of standards for determining, assessing and managing social and environmental risk in project financing. We signed the Equator Principles, which are applied to all our projects irrespective of the USD10 million capital costs threshold. We are actively involved in a strategic review launched by the Equator Principles Association in October 2010 to determine the future of the Equator Principles and to encourage greater consistency in the application of the Equator Principles in our markets. Under the Equator Principles, Environmental and Social risks are classified as: low (Category C), medium (Category B) or high (Category A). We report annually on the number of advisory and lending mandates executed by [our bank]" (F24).

Another interviewee highlighted their bank's commitment to ensuring that all lending is strictly against social and environmental criteria,

"Well in terms of responsibility to our investment and lending decisions, all of our projects are screened by the environment and sustainability department. We will decide the appropriate steps in terms of both due diligence and structuring of the project, to ensure that the project meets our standards" (F4).

Another interviewee emphasised the importance of ensuring that companies fit lending criteria on social and environmental issues relating to the Equator Principles,

"Our major concern is to make sure that the companies that we are lending to actually fit the criteria that we set out to ensure that they are green and sustainable" (F12).

One interviewee mentioned the 'three pillars' applied to all investment or lending projects, 


\begin{abstract}
"Sustainability, coming at it from my perspective, I would say it's one of the key elements of the strategy of the bank. We have three key pillars, which every project is required to meet, and these are the tests of transition. How does the project contribute to the transition to market economy process? ... So when you ask about the responsibility in investment and lending decisions, everything is screened for its environmental and social impact. All of the operations we do" (F5).
\end{abstract}

Both of the above quotes suggest from a Becksian and Giddensian theoretical perspective that following the Equator Principles were interpreted as a means of conveying and assuring the trustworthiness of the banks' compliance with the sustainability lending criteria. In this way, these 'pillars' and lending criteria were seen as mechanisms of re-embedding societal trust in the banking sector in the face of global warming and climate change.

Interestingly, although aware of the Equator Principles, and the social and environmental issues covered by them, one interviewee seemed a little uncertain of their name,

"The bank is a member of - what do you call it Equator Principles. So, any transaction or project that the bank finances need to comply with the Equator Principles. So that covers all social and environmental aspects" (F8).

This suggests that even though the Principles are being applied to rebuild trust, interpreting the utterance through a Giddensian, there is a lack of 'buy-in' to this substantial external initiative. Perhaps the Equator Principles are more about managing reputational risk than a genuine attempt to rebuild and nurture societal trust, which is in line with a business case, or instrumental ethics scenario (Solomon, 2020). There was further evidence of an instrumental ethics approach to implementing sustainability lending initiatives, such as the Equator Principles. One interviewee did however underline the importance of also making financially feasible lending decisions, although this priority seemed to be a 'given' after the fulfilment of socially acceptable criteria were met, 
"We need to be convinced that there is a social return, otherwise we cannot lend, but we also need to be convinced that we are going to get our money back. Otherwise, also, we cannot lend" (F13).

A similar, instrumental ethics approach is enshrined in the following comment, from the senior financial officer from a mainstream bank,

"We have an obligation to produce a certain return for our shareholders, as does every other bank. So I think if you can be nice to the environment as well, then great, but if there are two competing options, one with a higher return than the other, then we would go with the higher return option" (F17).

It is interesting that this rather short-sighted and outdated view persists. Separating profit and return from sustainability was proven invalid through the growth and expansion globally of the responsible investment movement. Specifically, the significant shift in attitude among the institutional investment community from one where they perceived socially responsible investment to involve sacrificing financial returns for social returns, to one where they started to appreciate how financial and social returns can be positively related, an enlightened shareholder approach (Solomon, 2020). Sadly, members of the banking community continue to be blind to these linkages. Or do they? Indeed, the (obvious) need to focus on profits and profitability as well as on social and environmental concerns was, as would be anticipated, highlighted by interviewees, such as ${ }^{7}$,

"If you said, 'I am green and, actually, it is going to cost us a lot more [money]', that probably would not fly [be accepted in our bank]. That is the commercial reality of an economic decision like that [sustainability practice]. So, the obstacle to that [sustainability practices] would be that [commercial reality]. But on the measurement thing, you are an

\footnotetext{
${ }^{7}$ This comment was in response to being asked about practical obstacles to developing and applying social and environmental practices.
} 
accountant; I am an accountant, our goal is to find consistency, useful information and relevant information" (F25).

The above quote indicates the need to clarify the commercial reality of sustainability practices. It seems significant to question banks' commitments to SD, sustainability in general. The primary focus of SD is not tied in with commercialism. The main ideology of this commercialism illustrates some aspects of financial capitalism. This form of capitalism seems to prioritize profitability issues to increase the legitimacy of organisational actions. However, the critique of this form of capitalism involves the absence of the main aspects of social and environmental profitability that could be achieved through many different ways such as the environmental saving of renewable energy practices, the revenues and saving from ecological and biodiversity practices. In addition, there are some possible benefits of social and environmental profitability that could be achieved to protect the environment for present and future generations (see Milne and Gray, 2013). The limits of environmental protection seem to be one of the main problematic themes of SD, especially in the context of business practices or actions that should be maintained in the main agenda of banking and business organisations. The process of considering these limits could be linked to Gray and Bebbington's (2001) questions that had been offered to identify (imagine) the framework of sustainable performance e.g. sustainability at what level of resolution and in what way. This argument would enrich the development of more organisational guidance on managing social and environmental business model within banks.

In relation to lending specifically for social, environmental and sustainability-oriented projects, it seemed the banks interviewed were in the process of developing their sustainability practices to account for the funding they have provided but also, increasingly, on the social and environmental impact of such lending, 
"We are using key performance indicators and statistics to measure our sustainable performance. There are a couple of things here. I mean we can certainly provide statistics on things like, you know we have lent so many millions of dollars for energy efficiency. We have put so many millions of dollars into renewable energy. You know we can do statistics like that..... You know syndicated dollars for our own dollars and what is gone into support green projects for example. But if you ask us some fundamental questions about impact, how do we measure the impact of our financing? So if we did say a municipal programme for water supply, how many additional people have got hooked up to a clean water supply? That's something that we are in the process of developing" (F5).

These mechanisms of accountability, such as measuring the number of people who have benefitted from a sustainability water initiative, represent another level of re-embedding. Such accountability mechanisms can further assist in rebuilding societal trust. Indeed, the development of accountability mechanisms such as enhancing transparency was evident in many of the interview discussions. In addition to publicly produced reporting on social and environmental impacts and issues, other methods of transparency and accountability mentioned by interviewees included weekly meetings of the whole bank to discuss issues arising, as well as engaging with stakeholders at 'green' conferences.

The important role of the UNEP FI in driving sustainability initiatives and adherence to social and environmental lending criteria was also highlighted by our interviews. In addition to the Equator Principles, the focus on the UN's environment programme on financial institutions is having a demonstrable impact on banks' behaviour and approaches, as discussed below,

"UNEP FI is a specific activity of UNEP, focused on financial institutions and they have developed a bunch of criteria which define what a sustainable bank would do. A sort of bundle/portfolio approach to achieving sustainable finance - several mechanisms all working together but separately to drive sustainable lending and sustainable approaches to finance" (F5). 
Indeed, one of our interviewees emphasised the importance of both UNEP FI and the Equator Principles in driving sustainability within the banking sector, due to the frameworks and governance they provide,

"We manage our sustainable practices through the governance structures and the frameworks that are already in place through the United Nations, through the Equator Principles and so on. So there are frameworks, the regional principles on human rights. There are frameworks that are already in place, it is just a question of continuing on the journey for these banks to make sure that they are managing all of their impacts through those frameworks" (F9).

Continuing the journey towards sustainability goals by following principles and continually improving performance in this area represents an important part of a dynamic process and suggests a dynamic approach to re-embedding: re-embedding does not simply happen with societal trust in banks being restored, but is, rather, the continuous path towards an improved and strengthened relationship of trust between banks and their stakeholders.

The interviewees generally discussed the development of governance around social, environmental and sustainability activities and $\mathbf{d s}$, indicating that in their view, corporate governance, good governance and value creation was inseparable from issues of sustainability.

\subsection{Sustainability initiatives as risk management and re-embedding mechanisms}

Sustainability initiatives, especially it seems, external sustainability initiatives, were perceived by the interviewees as risk management mechanisms, implemented primarily, it seems, as a means of managing reputational risks that could arise due to potential reputational damage was a bank to be considered unsustainable. From a Becksian theoretical perspective (2010) our findings suggest that banks are developing initiatives as they are increasingly 
aware of societal concerns regarding climate change and social issues. These concerns are engendering societal expectations that banks and other financial institutions should be acting more responsibly and should be enacting SD. These societal expectations also represent significant reputational risks for banks that are not adopting sustainability initiatives. Further, there seems to have been a recent shift in societal attitudes towards issues relating to sustainability that has acted as another factor driving banks to develop sustainability initiatives. With reference to Giddens' framework (1991), sustainability initiatives represent re-embedding mechanisms, their implementation seeking to rebuild societal trust. Indeed, interviewees commented that there is an ongoing transformation in societal attitude concerning sustainability resulting in a rise in demand from their client base for financial services that take account of social and environmental issues as indicated in the following quote

"There is a massive demand at the moment for our services. There is a culture change going on. I mean we are inundated by depositors, who believe in the mission of our organisation. I think the sustainability movement is growing and ethical finance is growing as well with demand for social mainstream" (F14).

Connected to this culture change is the need for banks to demonstrate their commitment to society, to legitimise their actions and strategies through adopting sustainability initiatives,

"I think, at the macro level, without sustainability the bank would not survive. So it is absolutely critical - but also corporate social responsibility is an important element of the bank. Maybe not in the 'immediate', the 'now' of the business, but certainly in terms of its reputation in the community and its standing in the community, it is taken very seriously" (F7).

This quotation resonates with Beck's (1997) comments that companies are now seen as either villains or heroes (see above), and the banks' evident desire to be perceived as the latter. 
Indeed, the same interviewee included reputational risk as one of the three main risks facing banks,

"The main challenges to the survival of any banking institution are centred in operational risk, reputational risk and credit risk" (F7).

It seems from our interview analysis that reputational risk management is partly if not wholly driving sustainability initiatives. However, in addition to risks from reputational damage, the interviewees also identified sustainability-related risks potentially arising from being in breach of environmental legislation. Indeed, one interviewee indicated that unless a bank perceives risk attached to sustainability issues they would be unlikely to pay such issues any attention,

"I think there needs to be a risk - I mean with all the environmental things, I think, they only look at it because they are worried about a fine. I think that's probably the main criteria for being more sustainable ... I think it's probably the only way because, generally, people will try to get away with what they can. So, I don't think banks are going to be sustainable just because they want to; they need to have an incentive to do so" (F8).

Another interviewee suggested that environmental issues would not be taken into account in banking decisions unless there was a reputational risk attached to their neglect,

"I do not think that banks take in the environmental issues when they are making investments, banks, I do not think they consider that, unless it is a sensitive political issue which might make the investment less attractive. They would take that into account" (F16).

This quotation again underlines the reputational risk management motivation underlying the implementation of sustainability initiatives, as the interviewee mentions sensitive political issues that clearly could affect the bank's reputation. 
In his risk society thesis, Beck refused to adopt a singular lens, instead of focusing on the intersection between 'the risk itself and public perception of it' (Beck 1992, P.55). This approach assists in the interpretation of our interview data in that the adoption and implementation of sustainability initiatives by the banks interviewed appears to be driven for the most part by potential risks arising from public perception of climate change and social factors: the risk of reputational damage to the banks if they do not implement sustainability initiatives.

\subsection{Sustainability initiatives as coping mechanisms}

There appeared to be a separation between the attitudes of our interviewees towards internal and external sustainability initiatives. Interviewees' views concerning external initiatives such as the adoption of the Equator Principles, as discussed above, tended to be more institutional, with less personal 'buy-in', and implementation being motivated by reputational risk management concerns. Where interviewees discussed internal sustainability initiatives and practices, they appeared to be more personally involved. It seemed that they were personally and individually committed to these initiatives, using the words 'we' and 'us' when discussing their implementation. Social and environmental awareness, and the escalating risks arising from irresponsible business practices, are engendering a shift in societal attitudes, but societal attitudes are reflected through employees in the banks themselves. Employees, as concerned and aware members of society, are also driving sustainability initiatives from the inside. Therefore, in addition to external pressures on banks to engage in SD and sustainable business practices, as well as to respond to external societal concerns, there are also internal drivers. Banks are not inanimate institutions but consist of, and depend on, the people who run them and the people who are employed by them. It is this intricate linkage to 'society' within institutions that is also engendering substantial change in 
attitude and practice. This thinking is in line with Giddens' predictions that a 'second wave' of response to the hazards posed by global warming, that involves, “...embedding it [climate change] in our institutions and in the everyday concerns of citizens" (Giddens, 2011, p.3). Further, we interpret these (mostly) internal sustainability initiatives as Giddensian coping mechanisms, assisting bank employees to believe they are reducing climate change risk, thereby creating a protective cocoon for themselves and rebuilding their ontological security. This is a misguided impression, as small-scale initiatives such as reducing paper consumption have little effect on global climate change, but day-to-day exercises such as using less water in the office, will make bank employees feel more secure, as they are 'doing something'. As coping mechanisms such initiatives were become embedded in the bank staff's everyday routines. For long-term effective approaches to sustainability, initiatives and strategies need to be genuinely embedded in the organisation and its employees. An example from our interviews where a sustainability initiative was implemented through engagement with the bank's employees is demonstrated by the following quotation,

“... We do have initiatives where, as a business, in our staff meetings we talk about things that we would like to do, that the staff generate. One of those was recycling, some years ago. So now if a member of staff comes up with a good idea we try and implement it" (F7).

Again, this interviewee seems concerned about his bank. He is seeking to honour a genuine commitment to these sustainability initiatives, as seen from his self-proclaimed desire to 'do' sustainability at a 'deeper level'. Note the use of 'we' in the interviewee's discourse: these sustainability initiatives are seen as arising from the employees themselves, they are bought into them, they associate with them and they are not separating the initiatives from themselves. By taking ownership of these initiatives, we suggest they are using them as coping mechanisms in the face of immeasurable and unsettling climate change risk. Another 
interviewee appeared to have a deeply-rooted commitment to sustainability, and especially social, initiatives, in relation to the bank's culture and history,

"Our general social projects, that we are not just a money making-machine, we are socially aware and we are aware, in part, of our heritage. It is important for us to be seen not just as a moneymaking machine but to actually be a part of the community, certainly in the UAE, and enable us to take a leadership role within society in the UAE" (F15).

Further, banks' ethical policies are now incorporating social and environmental concerns such that these issues are effectively mandatory considerations for the organisations,

"The ethical policy is a policy which has existed for 20 years. It is been updated five times in that period. This policy has very strict guidelines that say that the bank will and would not finance, based on their activity. So on the ecological side, the environmental side, which is what you are interested in, it [the ethical policy] has got statements such as "We would not finance a business that is involved in the extraction of fossil fuels" (F6)

These findings contrast with earlier research that found a total absence of ethical discourse in investor-company engagement on climate change, with the discourse being subsumed in a risk-dominated discourse focused entirely on financial materiality (Solomon et al., 2011). Instead, we found evidence from the banks interviewed of consideration of emotional, ethical and ecological motivations for implementing sustainability initiatives. This suggests a shift among financial institutions towards a multi-motivational model, with banks embracing sustainability approaches for a range of reasons, rather than purely financial considerations: reducing reputational risk whilst simultaneously pursuing socially responsible objectives for the 'right' reasons. 


\section{EighthsFifth: Concluding thoughts}

The collected empirical data provides significant contribution to sustainability and green banking literature for the following reasons. First, it shows how to Usinguse Beck's risk society theory as a theoretical lens through which-to interpret banks' behaviour in manging reputational risks and building the societal trust. Second, this paper demonstrates the views of $\underline{\text { senior bankers toward the implementation of sustainability initiatives at their core business }}$ activities. Third, othe interview data allows a number of concluding comments and suggestions to be made.

Our findings resonate with earlier research into institutional investors' attitudes towards climate change that found their engagement and dialogue with companies around climate change issues to be imbued with a risk discourse: their initiatives and actions were dominated by risk management motivations. The overriding motivation for banks to implement sustainability initiatives appears to be management of reputational risk, linked to an understanding that societal attitudes had shifted such that all institutions and organisations were now expected to pursue SD. However, we found some evidence that genuine change was afoot, with interviewees displaying deep, personal commitment to a sustainable approach, implementing social and environmental initiatives for more ethical rather than riskbased reasons. These rather different findings tended to involve internal sustainability initiatives, rather than external. From the perspective of Giddens' theoretical work, sustainability initiatives also represent a means of re-embedding, of rebuilding trust among banks' shareholders in the wake of the financial crisis and in response to the potentially catastrophic systemic risks associated with climate change and global warming.

It seems that the banks are 'doing sustainability' in a manner similar to that encapsulated in an industrial society perspective rather than from a more advanced, late phases risk society perspective (Beck, 1999). They are attempting to control and manage sustainability issues in 
a similar way to the study of private climate change reporting found investors had effectively

'fallen prey to self-deception' that climate change represents a risk that can be managed and had therefore turned to seek to manage the unmanageable, hiding behind their comfortable financial view of the world where everything can be modelled (Solomon et al., 2011). Lastly, we suggest that the internal sustainability initiatives were interpreted, through Giddens' theoretical framework, as a means of coping with the risks of the high consequences of elimate change, thereby assisting bank employees to recreate their protective cocoon and restore their shattered ontological security. There are two groups of implications of this paper that could benefit the professional practice and society. The first group of implications includes managerial implications that benefit business managers (bankers). The second group of implications involves the non-managerial implications that could benefit other stakeholders e.g. SD researchers and activists, customers, supervisory authorities, government, professional bodies, customers, and shareholders. The managerial implications involve the possibility of developing an internal (organisational) code of business practices to use sustainability initiatives to organise and manage the social and environmental activities of banking operations. This code would represent an internal organisational guide to manage reputational risks and rebuild the societal trust such as green lending and borrowing policy and commercialising social and environmental investments. In addition, this paper could be used to develop another organisational account to manage the organisational contribution to environmental enhancement and improvement. This account could involve the organisational impact on the less influential stakeholders who are negatively affected by environmental damage.

The second group of implications involves some practical benefits that could be delivered to $\underline{\text { sustainability initiatives setters and regulators to explore any future compulsory framework of }}$ sustainability reporting standards. It involves the practical considerations that should be 
raised and maintained in these initiatives such as the sustainability to manage sustainability risks. Furthermore, this paper could be used to build up the internal and external organisational capabilities (activities) to include the most significant imperatives of SD in the core business activities.

The theoretical implication reveals that sustainability initiatives are imbued with reputational $\underline{\text { risk management and also indicates that some sustainability initiatives were interpreted as }}$ coping mechanisms and mechanisms of re-embedding. Our analysis allows conclusions to be drawn on the effectiveness of initiatives introduced by the banks interviewed in enhancing societal welfare, protecting the environment, and working towards managing climate change $\underline{\text { risks. The managerial implication of this paper could help sustainability initiatives setters and }}$ financial institutions to develop and explore more coherent incentives and motivations to rebuild their trust and reputation.

Nevertheless, it is hoped that future research will be undertaken regarding specific ways in which banks and financial institutions are able to adapt compulsory sustainability measures and/ or initiatives to create tangible enhancement for society and the environment. In addition, this kind of research may explore more organisational sustainability practices to rebuild societal trust and managing the high consequence risks of climate change and financial crisis. 


\section{References}

Aklitar, S. (2007). Sustainability and Challenges. Economic Review, 9(10), 43-47.

Aracil, E., Nájera-Sánchez, J.-J. \& Forcadell, F. J., 2021. Sustainable banking: A literature $\underline{\text { review and integrative framework. Finance Research Letters }}$

Atkins, J. and Atkins, B. (2019). Around the World in 80 Species: Exploring the Business of Extinction, Routledge, UK.

Atkins, J. and Macpherson, M. (2019). "Developing a Species Protection Action Plan - An Integrated Approach for Taxonomies, Reporting and Engagement for the Financial Services Sector", Concept Paper circulated at Investec Bank’s Natural Capital, Species Extinction and Sustainable Financial Markets Event, 30th May.

Baumgartner, R. J., and Ebner, D. (2010). Corporate sustainability strategies: Sustainability profiles and maturity levels. Sustainable Development, 18 (2). 76-89.

Beck, T., Demirgüç-Kunt, A., and Levine, R. (2010). Financial institutions and markets across countries and over time: The updated financial development and structure database. The World Bank Economic Review, 24 (1). 77-92.

Beck, U. (1987). The Anthropological Shock: Chernobyl and the Contours of the Risk Society. Berkeley Journal of Sociology. Vol. 32(1). 153 - 165.

Beck, U. (1992). Risk Society: Towards a New Modernity, London.

Beck, U. (1997). Sub-politics: ecology and the disintegration of institutional power", Organization and Environment, 10 (1). 52-65

Beck, U. (1999). World Risk Society. Blackwell Publishers, Cambridge.

Beck, U. (2007). Beyond Class and Nation: Refraiming Social Inequalities in a Globalised World. The British Journal of Sociology. Vol 58 (4).

Beck, U. (2009). World at Risk. Polity Press. Cambridge. 
Beck, U., Giddens, A., Lash, S. (1994). Reflexive Modernization: Politics, Tradition and Aesthetics in the Modern Social Order. Stanford University Press. California.

Berglof, E. (2011). A European perspective on the global financial crisis, Corporate Governance: An International Review, 19(5). 497-501.

Bihari, S. C. (2010). Green Banking-Towards Socially Resonsible Banking in India. Journal of Business Insights and Transformation, October, 4(1). 82-88.

Boiral, O. (2006). Global warming: should companies adopt a proactive strategy? Long Range Planning 39(3). 315-330.

Bryman, A. and Bell, E. (2007). Business Research Methods. 2nd Ed. Oxford, Oxford University Press.

Bryson, D., G. Atwal, A. Chaudhuri, and K. Dave. (2016). “Antecedents of Intention to Use Green Banking Services in India.” Strategic Change (25). 551-567.

Burgess, A., Wardman, J., Mythen, G. (2017). “Considerng risk: placing the work of Ulrich Beck in context", Journal of Risk Research, editorial, November.1-5.

Contreras, G., W.B.Bos, J. \& Kleimeier, S., 2019. Self-regulation in sustainable finance: The adoption of the Equator Principles. World Development, (122). 306-324.

Conyon, M., Judge, W. Q. and Useem, M. (2011). Corporate governance and the 2008-2009 financial crisis, Guest Editorial, Corporate Governance: An International Review, 19(5). 399404.

Coulson, A. B., (2009). How Should Banks Govern the Environment? Challenging the Construction of Action Versus Veto. Business Strategy and the Environment, 18(3). 149-161. Deepa, P., and D. C. Karpagam. (2018). “A Study on Customer's Awareness on Green Banking in Selected Public and Private Sector Banks with Reference to Tirupur." International Journal of Advanced Research and Development 3 (1). 58-63. 
Delgado-Márquez, B. L., and Pedauga, L. E. (2017). Environmental behavior and MNEs: A strategy pulled by stakeholder engagement. Business Strategy and the Environment, 26(7). 927-939.

Dell'Atti, S., Trotta, A., Iannuzzi, A. P., and Demaria, F. (2017). Corporate social responsibility engagement as a determinant of bank reputation: An empirical analysis. Corporate Social Responsibility and Environmental Management, 24(6). 589-605.

Englert, M. R., Koch, C., and Wüstemann, J. (2018). The effects of financial crisis on the organizational reputation of banks: An empirical analysis of newspaper articles. Business and Society, $1-35$.

Fanasch, P. (2019). Survival of the fittest: The impact of eco-certification and reputation on firm performance. Business Strategy and the Environment, 28(4), 611-628.

Fombrun, C. J. (2005). A world of reputation research, analysis and thinking-building corporate reputation through CSR initiatives: Evolving standards. Corporate Reputation Review, 8(1). 7-12.

Forcadell FJ, Aracil E, Ubeda F.(2020). "Using reputation for corporate sustainability to tackle banks digitalization challenges", Business Strategy and the Environment, 1-13.

Forcadell, F. J., and Aracil, E. (2017). European banks' reputation for corporate social responsibility. Corporate Social Responsibility and Environmental Management, 24(1). 1-14. Gallego-Alvarez, I., and Pucheta-Martínez, M. C. (2019). Environmental strategy in the global banking industry within the varieties of capitalism approach: The moderating role of gender diversity and board members with specific skills. Business Strategy and the Environment, 347-360.

Giddens, A. (1987). Social Theory and Modern Sociology. Stanford University Press. California. 
Giddens, A. (1990). The Consequences of Modernity. Stanford University Press. Stanford California.

Giddens, A. (1991). Modern and Self-Identity: Self and Society in the Late Modern Age. Blackwell Publishing. Cambridge.

Giddens, A. (1992). The Transformation of Intimacy: Sexuality, Love, and Eroticism in Modern Societies. Stanford University Press.

Giddens, A. (1994). Living in a Post-Traditional Society. In Beck, U., Giddens, A., and Lash, S. (eds), Reflexive Modernisation: Politics, Tradition and Aesthetics in the Modern Social Order. 56 - 109. Polity. Cambridge England.

Giddens, A. (1998). Risk Society: The Context of British Politics. In Franklin, J. (eds). The Politics of Risk Society Order. Polity Press. Cambridge.

Giddens, A. (1999). Risk and Responsibilities. The Modern Law Review. Vol. 62(1). 1 - 10.

Giddens, A. and Pierson, C. (1998), Conversations with Anthony Giddens: Making Sense of Modernity, Blackwell, Oxford.

Giddens, A. (2009). Sociology (Sixth Edition). Cambridge, Policy Network: Polity. Giddens, A. (2011). The Politics of Climate Change, Polity Press, Cambridge, UK.

Gray, R. and Bebbington, J. (2001). Accounting for the Environment. 2nd Ed. London: SAGE Publications Ltd.

Gray, R. and Milne, M. (2002). Sustainability Reporting: Who's Kidding Whom. Chartered Accountants Journal of New Zealand, 81(6). 66-70.

Hubbard, G. (2009). Measuring organizational performance: Beyond the triple bottom line. Business Strategy and the Environment, 18(3), 177-191. https://doi.org/10.1002/bse.564 Jabbour, LS, Jabbour, CJC. (2009). Are supplier selection criteria going green? Case studies of companies in Brazil. Industrial Management and Data Systems 109(4). 477-495. 
Jeucken, M. (2004), Sustainability in Finance- Banking on the Planet. Netherland: Eburon Academic Publishers.

Jeucken, M. (2010). Sustainable finance and banking: The financial sector and the future of the planet. Routledge.

Kapoor, N., Jaitly, M., and Gupta, R. (2016). “Green Banking: A Step Towards Sustainable Development." International Journal of Research in Management, Economics, and Commerce 6 (7). 69-72.

Kay, J. (2012). The Kay Review of UK Equity Markets and Long-Term Decision Making, Final Report, July.

Kim, G., Shin, B., and Lee, H. G. (2009). Understanding dynamics between initial trust and usage intentions of mobile banking. Information Systems Journal, 19(3). 283-311.

Kyriakos, C. et al., 2021. A new practical methodology for the banking sector to assess $\underline{\text { corporate sustainability risks with an application in the energy sector. Sustainable Production }}$ and Consumption.

Lai, A., Melloni, G., and Stacchezzini, R. (2016). Corporate sustainable development: Is 'integrated reporting' a legitimation strategy? Business Strategy and the Environment, 25(3). $165-177$.

Lindenberg, N., and Volz, P. (2016). Green Banking Regulation-Setting out a Framework. UN City of Bonn: German Development Institute.

Macve, R. and Chen, X. (2010). The "Equator Principles": A Success for Voluntary Codes?. Accounting, Auditing and Accountability Journal, 23(7). 890-919.

Masukujjama, M., Siwa, C., Mahmu, M., and Alam, S. (2016). "Bankers' Perception of Green Banking: Learning From the Experience of Islamic Banks in Bangladesh.” Malaysian Journal of Society and Space, 12(2). 
Mehedi,S., Kuddus, M., and Maniruzzaman, M. (2017). "The Identification of Bankers' Perception Toward Indicators For The Adoption Of Green Banking In Bangladeshi Scheduled Commercial Banks.” Journal of Internet Banking and Commerce 22 (2). 1-18.

McElroy, M. and Engelen, J. V. (2012). Corporate Sustainability Management, 1st Ed. New York: Earthscan.

Miles, M. B., Huberman, M. and Saldaña, J. (2014). Qualitative Data Analysis; A Methods Sourcebook. 3rd Ed., SAGE Publications Inc .

Milne, M. J. and Gray, R. (2013). W(h)ither Ecology? The Triple Bottom Line, the Global Reporting Initiative, and Corporate Sustainability Reporting. Journal of Business Ethics, $118(1), 13-29$.

Miras-Rodríguez, M., Carrasco-Gallego, A., and Escobar-Pérez, B. (2015). Has the CSR engagement of electrical companies had an effect on their performance? A closer look at the environment. Business Strategy and the Environment, 24(8). 819-835.

Moxey, P. and Berendt, A. (2008). Corporate governance and the credit crunch, ACCA Discussion Paper, November, ACCA, London.

Nienaber, A. Hofeditz, M., and Searle, H. (2014). Do we bank on regulation or reputation? A meta-analysis and meta-regression of organizational trust in the financial services sector. International Journal of Bank Marketing, 32(5). 367-407.

Orlitzky, M., Schmidt, F. L., and Rynes, S. L. (2003). Corporate social and financial performance: A meta-analysis. Organization Studies, 24(3). 403-441.

Ortiz-de-Mandojana N, and Bansal, P. (2015). The long-term benefits of organizational resilience through sustainable business practices. Strategic Management Journal 37(8). 16151631. 
Park, S. B. (2018). Multinationals and sustainable development: Does internationalization develop corporate sustainability of emerging market multinationals? Business Strategy and the Environment, 27(8). 1514-1524.

Pérez, A., and del Bosque, I. R. (2015). How customer support for corporate social responsibility influences the image of companies: Evidence from the banking industry. Corporate Social Responsibility and Environmental Management, 22(3). 155-168.

Prakash Pillai, R., and Praveen Raj, D. (2019). "Perspective and Usage Patterns of Green Banking Services: A Cross-Sectional Analysis of Customers From Selected Banks in Kerala.” Research Review International Journal of Multidisciplinary 4 (2). 285-292.

Prerana, S. and Arup, R. (2020). “A Scientometric analysis of literature on Green Banking”, Journal of Sustainable Finance and Investment

Raut, R., Cheikhrouhou, N., and Kharat, M. (2017). "Sustainability in the banking industry: A strategic multi-criterion analysis", Business Strategy and the Environment, Volume 26, Issue 4.

Relaño, F. (2011) "Maximizing social return in the banking sector", Corporate Governance: The International Journal of Business in Society, 11(3).

Ruiz, B., Esteban, A., and Gutierrez, S. (2014). Determinants of reputation of leading Spanish financial institutions among their customers in a context of economic crisis. BRQ Business Research Quarterly, 17(4). 259-278.

San-Jose, L., Retolaza, J. L. and Gutierrez-Goiria, J. (2011). Are Ethical Banks Different? A Comparative Analysis Using the Radical Affinity Index. Journal of Business Ethics, (100). 151-173.

Sarma, P. and Roy, A. (2020). A Scientometric analysis of literature on Green Banking (1995-March 2019), Journal of Sustainable Finance and Investment, DOI: $10.1080 / 20430795.2020 .1711500$ 
Scholtens, B. (2009). Corporate social responsibility in the international banking industry. Journal of Business Ethics, 86(2). 159-175.

Scholtens, B. (2017). Why finance should care about ecology. Trends in Ecology and Evolution, 32(7). 500-505.

Scholtens, B. and Dam, L. (2007) "Banking on the Equator: Are banks that adopted the Equator Principles different from non-adopters?”, World Development, (35).1307-1328.

Shen L, Olfat L, Govindan, K., Khodaverdi, R., and Diabat, A. (2012). A fuzzy multi criteria approach forevaluating green supplier's performance in green supply chain with linguistic preferences. Resources, Conservation and Recycling 74(1). 170-179.

Solomon, J. F., Solomon, A. Joseph N. L. and Norton, S. D. (2011). "Private Climate Change Reporting: A Discourse of Risk and Opportunity?", Accounting, Auditing and Accountability Journal, 24(8).1119-1148.

Solomon, J. (2020, forthcoming). Corporate Governance and Accountability, John Wiley and Sons Inc., 5th edition, Chichester, UK.

The Equator Principles (2014). The Equator Principles Implementation Note, It could be accessed via https://equator-principles.com/ep-association-news/implementation-note/ (Accessed on $16^{\text {th }}$ June 2020)

Torelli, R., Balluchi, F., and Lazzini, A. (2019). Greenwashing and environmental communication: Effects on stakeholders' perceptions. Business Strategy and the Environment, 407-421.

UNEP FI, (2011). United Nations Environmental Programme Finance Initiative. [Online] Available at: https://www.unepfi.org/[Accessed 14th October 2019].

Walker, D. (2009). A Review of Corporate Governance in UK Banks and other Financial Industry Entities, The Association of Chartered Certified Accountants (ACCA), The Walker Review Secretariat, London 26 NovemberOctober . 
Yip, A. W., and Bocken, N. M. (2018). Sustainable business model archetypes for the banking industry. Journal of Cleaner Production, 174, 150-169. 